\title{
A HISTORIOGRAFIA DO BRASIL, 1808-1889 (*) (**).
}

Revendo a historiografia do século XIX aparecida no Brasil nas quatro décadas posteriores à Primeira Grande Guerra, salientam-se três fatôres (1). Em primeiro lugar, a produção foi grande, comparada com a dos períodos anteriores. Depois, não apenas historiadores, mas, também economistas, antropólogos e sociólogos contribuiram para a apresentação de trabalhos históricos. Por fim, os textos foram mais analíticos que narrativos, refletindo a crescente profissionalização do mister do historiador.

No Brasil, a procura da tradição, assim como a sêde pelo conhecimento do passado, que representam, uma e outra, manifestações de nacionalismo, ajudam a explicar o escopo e volume de produção. O aparecimento de maior público leitor, produto de uma classe média em crescimento, foi outro fator. Ainda assim, não há exagêro em presumir-se que as turbulentas décadas de após-guerra, à medida que se acelerava o índice de modernização do Brasil, encorajaram muitos a olhar o passado em busca de uma resposta para os múltiplos problemas do

\footnotetext{
(*). - Tradução de Maria Lúcia Carneiro, do artigo publicado in "The American Historical Review", vol. XL, n.o 2, malo de 1960 (Nota da Redaçăo).

(**). - $O$ autor é Associate Professor na Princeton University. Este é um artigo duma série historiográfica. O artígo sôbre o período posterior a 1889 está sendo preparado por George C. A. Boehrer da Georgetown University.

(1). - Subvenção do Princeton University's Research Commitee, compreendendo trabalho e manutenção no verão de 1956, financiou as pesquisas necessárias à feitura dêste artigo. O autor deseja manifestar os seus agradecimentos a Charles Gibson, Lewis Hanke, Robin A. Humphreys, Alan K. Manchester, Alexander Marchant e ao falecido Otávio Tarquínio de Sousa, pelo exame crítico que dispensaram a êste artigo, assim como pelas sugestōes bibliográficas que fizeram. Francis M. Rogers, da Harvard University, conferiu gentilmente diversas fontes de informaçōes.

E' um prazer, também, agradecer as freqüentes observações, críticas e revisões dêste artigo feitas por Bárbara Hadley Stein.
} 
presente. Alguns procuraram aí a ordem e a estabilidade aparentes, enquanto outros buscaram descobrir a razão de seus predecessores terem deixado tantos problemas sem solução. Os. interêsses, preconceitos e ideais da geração "Brasilianista" do após-guerra refletem-se na produção historiográfica dêsses anos.

Nos anos do após-guerra, três décadas depois da proclamação da República, em 1889, o desapontamento e o cinismo. tomaram o lugar do otimismo dos primeiros tempos da República. Sentiu-se que esta prolongara, em vez de eliminá-la, a centralização do poder político combatido amargamente nos. últimos anos do Império. As deficiências óbvias da "primeira "ou "velha" República (1889-1930) levaram a uma revisão. da história do Império e de sua principal figura, Dom Pedro II, enquanto o levante de Vargas em 1930, a convocação de uma Assembléia Constituinte e a Ditadura que se seguiu, induziram alguns historiadores a investigar os problemas similares enfrentados pela Assembléia Constituinte e pela autocracia das décadas de 1820 e 1830 . Apareceram, também, monografias sôbre os primeiros ciclos econômicos do Brasil e sôbre a origem tardia da industrialização no século XIX. Finalmente, numa geração após a abolição da escravidão e o início da maciça emigração européia, tornou-se óbvio ter o Brasil falhado na integração do negro liberto e seus descendentes, e em extensão menor, do emigrante. Um dos problemas dêste exame da historiografia brasileira do após-guerra, relativa ao período de 1808-1889, é verificar se os historiadores, sob a pressão dos problemas contemporâneos, reinterpretaram realmente o passado brasileiro ou apenas focalizaram episódios esquecidos e negligenciados. Com êsse objetivo em mente, não fizemos, entretanto, nenhuma tentativa de analisar ou sequer registrar tôdas as publicações existentes. Os trabalhos foram selecionados, tendo-se em vista, antes de tudo, ilustrar as tendências historiográficas ou oferecer como guias bibliográficos para pesquisas futuras (2) .

(2). - No preparo de uma bibliografia seletiva da historiografia brasileira de após-guerra, foram consultadas as seguintes publicações: Handbook of Latin American Studies (HLAS) (1936-1951); Hispanic American Histocal Review (HAFR) (1918-); William Berrien e Rubens Borba de Moraes, eds., Manual bibliográfico de estudos brasileiros (Rio de Janeiro, 1949); Américo Jacobina Lacombe, Brasil. Periodo nacional (México, 1956); Bureau for Research in Latin America, Economic Literature of Latin America, (2 vols., Cambridge, Mass., 1935-1936), I; Revista do arquivo municipal de sáo Paulo (RAMSP) (1934-); Biblioteca nacional do Rio de Janeiro, Documentos históricos (1928) e Anais (1919); Revista do Instituto Hỉstórico e Geográfico Brasileiro (REIHGB) (até 1930 os números que precedem o ano de publicação referem-se ao tomo e a partir 
A historiografia recente sôbre: a : primeira fase capital na evolução do Brasil moderno, a fase que se estende da chegada da família real portuguêsa (1808), fugindo à invasão do exército francês, e a abdicação de Dom Pedro I, em 1831, com seu subseqüente retôrno a Portugal, pode ser reduzida às obras principais de dois historiadores, Tobias Monteiro e Otávio Tarquínio de Sousa, além de algumas raras sínteses mais sugestivas que definitivas (3) e de grande número de estudos monográficos que, não sendo, embora, exaustivos, têm sua utilidade.

Entre o importante trio de historiadores pré-1920 (ou "mais antigos") que estudaram esta era - - Armitage, Varnhagen, Oliveira Lima (4) - apenas o primeiro encarou o período como um todo. $\mathrm{Na}$ realidade, : Armitage tratou a era Joanina (1808-1821) de modo sumário, com o fito de se concentrar sồbre o Primeiro Reinado (1821-1831), período que podia discutir com conhecimento de causa por ter residido no Brasil e ter sido amigo chegado do jornalista e político brasileiro Evaristo da Veiga (5) : Nas suas mãos o nascimento e queda do Primeiro Reinado transforma-se : na tragédia pessoal de

de 1930 ao volume); Revista dó Institutó Histórico e Geográfico de Isão Paulo; Congresso de história nacional. Primeiro, Rio de Janeiro, 1914, Atas (5 vols., Rio de Janeiro, 1915-1917), Segundo, Rio de Janeiro, 1931, Anais (5 vols., 1934-1936), Terceiro, Rio de Janeiro, 1938, Anais (10 vols., 1939-1944), Quarto, Rio de Janeiro, 1949, Anais (13 vols., Rio de Janeiro, 1950-1952); Revista de História .(São Pạulo) (1950-); Donald Pierson, ed., Survey of the Literature on Brazil of Sociological Significance Published up to 1940 (Cambridge, Mass., 1945), esp. págs. 32-53.

(3). - Tobias do Rêgo Monteiro, História do Império; A elaboração da Independência. Rio de Janeiro, 1927 e o Primeiro Reinado, 2 vols. Rio de Janeiro, 1939-1946; Otávio Tarquínio de Sousa, A Vida de D. Pedro I, 3 vols. Rio de Janeiro, 1952. Há o ensaio bibliográfico de Tarquínio de Sousa, "Independência, Primeiro Reinado, Regência", em William Berrien e Rubens Borba de Moraes, e ds., Manual bibliográfico de estudos Brasileiros, 408-423 e as sínteses por Caio Prado Júnior, Evolução política do Brasil. Ensaio de interpretação dialética da história brasileira. 2a. ed. São Paulo, 1947, e por Lídia Besouchet, Mauá y su epoca (Buenos Aires, 1940), 11-81.

(4). - João Armitage, História do Brasil desdé o periodo da chegada da família de Bragança em 1808 até a abdicação de D. Pedro I em 1831. Eugênio Egas e Garcia Júnior, eds., 3a..' ed. brasileira, Rio de Janeiro, 1943; Francisco Adolfo de Varnhagen," "História da Independência do Brasil", RIHGB, 79 (1916), 25-594; Manuel de Oliveira Lima, Dom João VI no Brasil. Prefácio por Otávio Tarquínio de Sousa, 2a. ed., 3 vols. Rio de Janeiro, 1945 e 0 movimento da Independência, 1821-1822. São Paulo, 1922.

(5) - Para uma discussão sôbre a autoria como também sôbre o primeiro tradutor brasiléro, ver José Honório Rodrigues, Teoria da História do Brasil. Introdução metodológica (São Paulo, 1948), 215-216. 
Dom Pedro que se teria apartado de seus correligionários destruindo a crença em sua adesão à monarquia liberal constitucional. A ênfase sôbre a monarquia ("o melhor instrumento para introduzir a civilização desejada") (6) e seus ministros foi continuada por Varnhagen, cujas publicações aparecem depois de 1850. Sua maior contribuição, "História da Independên.cia do Brasil" (7), como supôs com acerto no último volume da História geral, foi o uso de fontes até então descuradas: jornais, panfletos e a correspondência de diplomatas inglêses, franceses ou austríacos na côrte do Rio de Janeiro. Escrevendo em 1850, - quando na Europa se construiam Estados, Varnhagen louvou sem restrições a monarquia. A última figura do trio de historiadores mais antigos, Oliveira Lima, seguiu de perto as pegadas de Varnhagen. Seus dois principais trabalhos também estudam Dom João VI e o movimento da independência. Em Dom João VI no Brasil (1909) buscou reabilitar a figura do monarca que fugira para o Brasil a bordo de um navio de guerra inglês e retornara a Portugal, com relutância, em 1821, para enfrentar a ira das Côrtes. A contribuição de Oliveira Lima foi o reexame e a reintegração de material já bem conhecido; seus trabalhos previram o recurso à psicologia para iluminar o círculo estreito da elite política daquele tempo, os personagens reais e burocráticos, seu caráter e suas fraquezas. Tomados em bloco, êsses historiadores mais antigos desprezaram a história econômica e social para focalizar a monarquia como a forja da Independência e da unidade do Brasil Imperial do século XIX. O "povo" como Oliveira Lima sugeriu (8), não era fator político.

Não surgiu na maior parte dos estudos históricos Joaninos e do Primeiro Reinado, aparecidos depois de 1920, nenhuma escola revisionista radical, pois ainda persiste uma preocupação com a elite política. Tobias Monteiro prometeu uma série de volumes sôbre a história do Império entre a chegada de Dom João VI em 1808 e abdicação de seu neto Dom Pedro II, em 1889. Ao morrer publicara apenas três volumes. Nos livros de Tobias Monteiro, predominou a nota anti-portuguêsa, em especial no primeiro volume, A elaboração da Independência. Desfaz aí a reabilitação tentada por Oliveira Lima,

(6). - Armitage, História, 316.

(7). - Francisco Adolfo de Varnhagen, História Geral do Brasil. Rodolfo Garcia e Capistrano de Abreu, eds., 5 vols., 3a. ed. São Paulo, 1927?-1936. A análise de Capistrano de Abreu (1882) sôbre a posição de .Varnhagen na historiografia brasileira foi reimpressa em ibid., III, 435-444.

(8). - Manuel de Oliveira Lima, o movimento da independência. 1821-1822, 36. 
de D. João VI apresentado agora como um homem fraco, ainda que de físico opulento, enquanto sua mulher se apresenta como uma mexeriqueira e uma reacionária degenerada. Usando ampla documentação, produziu Tobias Monteiro um quadro de família bem pouco lisongeiro (9). Os portuguêses perderam o Brasil por ignorarem que não poderiam ser mantidas as antigas relações coloniais. Tobias Monteiro ao terminar êste volume relembra aos leitores, como o haviam feito os historiadores mais antigos, que a monarquia, a despeito dos seus erros, forjara, na independência, a unidade.

Não é de estranhar que o trabalho subseqüente de Tobias Monteiro, O Primeiro Reinado, refletisse as condições de 1920 e 1930, quando o Brasil estava açoitado pelas correntes revolucionárias de reforma constitucional. Dedicou o principal. setor do volume, que infelizmente termina com os acontecimentos de 1827, à análise da constituição "autorizada" por Pedro I em 1824, salientando que o "poder moderador" ("chave de tôda a estrutura política" como afirmava a Constituição) conduziria ao abuso e à acusação de que representa a fonte do "poder pessoal" de Dom Pedro (10). Tobias Monteiro observou que a suspensão cavalheiresca feita por Dom Pedro da cláusula sôbre os direitos civis constitucionais com o fim de esmagar a revolução pernambucana de 1824, à qual dedicou metade do volume, confirmou os piores temores da oposição li-. beral. A sua apresentação da principal figura do Primeiro Reinado recorda a que traçara Armitage, contemporâneo de D. Pedro I. D. Pedro era de formação portuguêsa, assim como portuguêses eram os seus conselheiros, e apenas sua ação no movimento da independência lhe dera uma popularidade efêmera. Pela sua intervenção constante nos negócios portuguêses, depois da proclamação da independência e por violações repetidas da sua própria constituição, forçou os liberais brasileiros - tanto os monarquistas institucionais (moderados) como seus colegas mais radicais (exaltados) e republicanos - a duvidar de sua lealdade à monarquia constitucional .

(9). - Objeções contra o retrato familiar pouco lisongeiro podem ser encontradas em Max Fleuiss, "Parecer... sôbre... A elaboração da independência, 1808-1823". RIHGB, 101 (1927), 399-418, e A. d'E. Taunay, A mis* são artística de 1816. Rio de Janeiro, 1912.

(10). - Para a crítica da interferência política de Dom Pedro ver Alexandre José Barbosa Lima Sobrinho, "A ação da imprensa em tôrno da constituinte. o Tamoio e A Sentinela", Segundo Congresso de história nacional, Anais, I, 339-410, e o fac-simile das reproduções do A Malagueta. Rio de Janeiro, 1945, e O Tamoio. Prefácio por Caio Prado Júnior, editado por Rubens Borba de Morais. São Paulo, 1944. 
O segundo entre os principais estudos sôbre o período Joanino e o Primeiro Reinado aparecido depois de 1920, A vida de D. Pedro I, por Otávio Tarquínio de Souza, em três volumes, abrange, em largo painel, os manipuladores do poder político desde o casamento dos pais de D. Pedro (1785) até a morte dêste, em Portugal (1834). De leitura eminentemente agradável, cheios de detalhes pessoais do pai e do filho, à maneira de Tobias Monteiro, os volumes são o resultado de anos de pesquisas, do uso amplo de manuscritos de aproveitamento recente ou de material publicado (11) e do grau de maturidade da historiografia brasileira. Tarquínio de Souza dedicou-se à biografia de Dom Pedro depois de publicar quase duas décadas antes uma análise da Assembléia Constituinte de 1823, além de outra dos golpes de estado de 1831 e 1840, e uma série de estudos biográficos de políticos eminentes do Primeiro Reinado e da Regência de 1830 (12) .

O que, no fundo, tentou Tarquínio de Souza foi reabilitar a figura de Dom Pedro I, assim como Oliveira Lima já o fizera com relação a Dom João VI, tarefa que se fêz possível graças à consulta dos manuscritos de Dom Pedro, finalmente colocados à disposição dos estudiosos no Museu Imperial de Petrópolis. Abordando a questão proposta um século antes por Armitage - a alienação de Dom Pedro do nativismo brasileiro ou do apôio nacionalista durante o tempo que transcorre entre sua coroação e sua abdicação (1822-1831) — transformou-a no

(11). - Para algumas das mais importantes fontes recentemente publicadas ver: Francisco Sierra y Mariscal, "Idéias gerais sôbre a revolução do Brasil e suas consequiências", Biblioteca nacional, Anais, XLIII-XLIV (1920-1921), 511-81, uma análise das revoluçções da independência, de conflitos e metas de partidos; Biblioteca nacional, Documentos para a história da independêncla. I Lisboa - Rio de Janeiro, 1923, contém manuscritos e material publicado sóbre o período, 1820-1826; o relatório do Ministro austríaco no Rio de Janeiro a Metternich em J. Figueira de Mello, “A correspondência do Barão Wenzel de Marschall", ibid., 77 (parte 1, 1914), "Cartas sôbre a revolução do Brasil", RIHGB, 51 (parte 1, 1888), 239-377.

(12). - "A mentalidade da constituinte", Segundo Congresso de História nacional, Anais, I, 243-313; História de dois golpes de estado. Rio de Janeiro, 1939; "Aspectos econômicos das lutas políticas no tempo do Império", Digesto econômico, 43 (1948); Bernardo Pereira de Vasconcelos e seu tempo. Rio de Janeiro, 1937; Evaristo da Veiga. São Paulo, 1939; Diogo Antônio Feijó (1784-1843). Rio de Janeiro, 1942, e José Bonifácio, 1763-1838. Rio de Janeiro, 1945. Tarquínio de Sousa discutiu o tratamento biográfico à história em ensaio introdutor a uma ediçāo de seus trabalhos em 10 volumes, Introdução à história dos fundadores do Império do Brasil. Ministério da Educação e Cultura. Serviço de documentação. Os cadernos de cultura, 109. Rio de Janeiro, 1957. Uma análise do trabalho de Tarquínio de Sousa, o historiador mais importante que tratou do Primeiro Império e Regência há muito já deveria ter sido feita. 
dilema psicológico de um monarca "educádo por si mesmo", de "idéias liberais e de conduta freqüentemente despótica", ansio:so por seguir as "idéias do tempo" de acôrdo com suas leituras de Filangieri e Benjamin Constant, e no entanto implacável no trato com os que se insurgiam contra sua autoridade. Quando a imprensa tomada de um nacionalismo crescente e encorajada pelas novas da Revolução de Julho de 1830 na França, passou a fazer pressão sôbre êle no sentido de reinar como um monarca constitucional, êle logo reagiu, confundindo monarquistas constitucionais com republicanos, e buscando apôio nos burocratas e comerciantes portuguêses. E' esta a contribuição que nos dá a A Vida de Dom Pedro I e que se reflete nos primeiros estudos de Tarquínio de Sousa sôbre Bernardo Pereira de Vasconcelos, Evaristo da Veiga e Diogo Antônio Feijó, que se opuseram ao despotismo de Dom Pedro, cuidando que as instituições brasileiras necessitavam de um monarca constitucional, não de um autocrata. Sua biografia do Imperador pretende ser uma análise erudita e equilibrada de uma personalidade chave dos anos de 1808-1831. No entanto, a omissão de aspectos fundamentais dessas décadas, tais como a insolvência financeira do Primeiro Império e a falência do Banco do Brasil, a manutenção da escravidão negra e do tráfico de escravos e suas relações com a sobrevivência da monarquia, ou a do imperialismo no Rio da Prata, diminui seu valor como biografia de uma época.

E' claro que a solução escolhida por Dom Pedro para o problema da reforma dentro da moldura do sistema antigo, consistiu em apoiar-se nas instituições autoritárias. Essa política, como o demonstraram tanto os historiadores mais antigos quanto os mais recentes, preservou o Brasil da anarquia interna e da divisão em pequenos estados soberanos, mas teve como resultado a transformação do Brasil num baluarte e exemplo de reação na América Latina. Monografias recentes mostram a estreita correlação existente entre a reação doméstica e a política exterior imperialista no Prata (13). Entre $18: 08$ e 1831

(13). - J. Street, "Lord Strangford and Rio de la Plata, 1808-1815" HAFR, XXXIII (nov., 1953), 477-510; Alan K. Manchester, "The Recognition of Brazilian Independence", ibid., XXXI (fev., 1951), 80-96; C. K. Webster, Britain and the Independence of Latin America, 1812-1830, Select Documents from the Foreign Office Archives (2 vols., Oxford, 1938), I; William R. Manning, ed., Dlplomatic Correspondence of the United States Concerning the Independence of the Latin American Nations $(3$ vols., 
os republicanos do Rio da Prata não deixaram de considerar o: Brasil uma ameaça constante de reação que a Grã-Bretanha al-. ternadamente refreiava e instigava. Logo após o início da Revo-; lução de Buenos Aires em 1810, Dom João VI, sua ambiciosa, mulher e seus ministros cuidaram de apoiar as autoridades espanholas em Montevidéu. Defensores do absolutismo, temiam, a expansão do virus revolucionário (14). Manchester e outros. sugerem que a Grã-Bretanha, em parte, reconheceu a indepen-. dência do Brasil para preservar a única monarquia da América: Latina contra as "tendências republicanas" das áreas vizinhas, (15) . O regime interno autoritário do Brasil e as repetidas intervenções militares no Prata, especialmente a ocupação da "Banda Oriental" (16), criaram na mente dos republicanos do Rio da Prata a imagem e o temor incômodo de um Império Brasileiro dependendo, para sobreviver, daquilo a que Alberdi chamará mais tarde "conquista e contra-revolução" (17).

Está ausente na historiografia recente do período 1808-. 1831 um amplo tratamento dos fatôres econômicos, como mos-'. tra o ensaio bibliográfico de Tarquínio de Sousa. Embora tre-chos de trabalhos da autoria de Caio Prado Júnior e Lídia Besouchet salientem as fôrças econômicas, a escassez de apôio: documental torna êstes ensaios, quando muito, estimulantes. Material disperso sôbre as condições econômicas da Colôniaa. durante a primeira década do século XIX pode ser achado nas. cartas da Bahia de Santos Vilhena (1802), publicadas em 1921.

New York, 1925), II, 669-868; William W. Kaufmann, British Policy and. the Independence of Latin America, 1804-1828, New Haven, 1951; Robin. A. Humphreys, Liberation in South America, 1806-1827. The career of James Paroissien. London, 1952. Ponto de vista respeitável sôbrè a política externa brasileira nesta época é o de Pandiá Calogeras, "A politica exterior do Império. I. As origens. II. O primeiro reinado", RMHGB, tomo especial, Contribuiçōes para a biografia de D. Pedro II. 2 'vols." Rio de Janeiro, 1927-1928. Ver também Carlos von Leenhoff, Contribui-: çōes para a história da guerra entre o Brasil e Buenos Aires. Tradução. de L. Brockman. Anotaçōes de Aurélio Pôrto. São Paulo, 1946.

(14). - Street, 493; Kaufmann, 58-59; Humphreys, 22, 32.

(15). - Manchester, 89 nota 93; Webster, I, 58; Kaufmann, 191.

(16). - Calógeras, II, 397-484 nega o direito brasileiro de incorporar a Banda Oriental contra o desêjo de seus habitantes.

(17). - Juan Batista Alberdi, El Brasil ante la democracia de América. Las disensiones de las repúblicas del Plata $g$ las maquinaciones del Brasil (Buenos Aires, 1946), 14. Cf. a afirmaçāo do Manifesto Republicano do Rio de Janeiro ems 1870 de que a monarquia brasileira "tem que ser forçosamente, além da origem e opressão no interior, a fonte perpétua da hostllidade e das guerras com os povos que nos rodeiam". Citado em João Cruz Costa, Contribuição à história das iđéias no Brasil (Rlo de Janeiro, 1956), 183. Cf. Richard B. MeCornack, 'Maximilian's Relations with Brasil", HAHR, XXXII (1952), 175-186. 
(18), onde são tratados a organização econômica baiana, as operações das plantações de açúcar, a política econômica e a causa da baixa densidade da população, assim como em respostas de proeminentes fazendeiros e comerciantes baianos a um questionário régio (19) recentemente publicadas. Em uma das respostas, Rodrigues Brito recomenda a abolição gradual da escravidão, a introdução da emigração chinesa e das fndias Orientais, clima favorável ao investimento do capital estrangeiro, e incremento da agricultura especializada. Estas publicações podem ser comparadas a uma análise das condições, econômicas do Brasil e recomendações de melhorias preparada depois da chegada de Dom João VI (20). Também fornecem outros pormenores sôbre as condições econômicas da época joanina a biografia, de autoria de Carneiro de Mendonça, do intendente Câmara (21) que ansiava por desenvolver uma indústria do ferro, diversos artigos sôbre política econômica (22) e monografias sôbre o arquiteto da política econômica de Dom

(18). - Luís dos Santos Vilhena, Cartas de Vilhena. Notícias soteropolitanas brasilicas. Anotadas por Braz do Amaral. 3 vols. Bahia, 1921-1935. José Honório Rodrigues comentou as deficiências desta edição na Teoria da História do Brasil, 235.

(19). - João Rodrigues de Brito, Cartas econômico-políticas sôbre agricultura e comércio da Bahia. Bahia, 1924 e uma edição ulterior, A economia brasileira no alvorecer do século XIX. Prefácio de F. M. de Góes Calmon. Salvador, 1949.

(20). - Antônio Luís de Brito Aragão e Vasconcelos, "Memórias sôbre -o estabelecimento do império do Brasil, ou nôvo império lusitano", Biblioteca nacional, Anais, XLIII-XIIV (1920-1921), 3-48. Há uma interpretação de mesquinho burocrata português sôbre a sociedade do Rio e a norma administrativa do período Joanino nas "Cartas de Luís Joaquim dos Santos Marrocos, escritas do Rio de Janeiro à sua família em Lisboa, de 1811 a 1821". Ibid. LVI (1934), 29-446. Ver também, Luís Edmundo da Costa, A côrte de D. João VI no Rio de Janeiro. 3 vols., Rio de Janeiro, 1939-1940.

(21). - Marcos Carneiro de Mendonço, "O Intendente Câmara", Segundo Congresso de história nacional, Anais, IV, 239-737, reeditado sob o mesmo título, Rio de Janeiro, 1933.

(22). - Alberto Carlos de Araújo Guimarães, "Ação cultural e política no govêrno de D. João VI", Terceiro congresso de história nacional, Anais, III, 257-292; Odilon Nogueira de Matos, "A Política econômica de D. Joāo VI: suas linhas gerais", Kriterion, 29-30 (julho-dezembro, 1954), 430-447; Ciro T. de Pádua, "Princípios econômicos vigentes no Brasil nas duas décadas do século dezenove", Boletim bibliográfico, I (outubro-dezembro, 1944), 21-35. Para análise do papel do Banco do Brasil, cuja política de empréstimos baseada em favoritismo político foi fator na acentuada inflação de 1820, ver a excelente monografia de João Batista Magalhães, "Jose Antônio Lísboa. Economista probo e patriota culto", RIHGB, 208 (julho-setembro, 1950), 110-185 e sua "Documentação do conselheiro José Antônio Lisboa, financista do Brasil Reino e Brasil Império", ibid., 213 (outubro-dezembro, 1951), 31-132. 
João, José da Silva Lisboa (23). Silva Lisboa, realista convicto e admirador ardente de Edmund Burke, apoiou o regime das concessões comerciais aos britânicos no tratado de 1810 para que o Brasil fôsse iniciado nos mistérios do crédito e expandisse o comércio colonial sôbre o resto do mundo.

A análise cuidadosa da influência britânica sôbre a economia brasileira dêsse período é uma das contribuições da historiografia brasileira de após-1920. Não só usaram os inglêses o mercado brasileiro a partir de 1808 para inundá-lo com tecidos de algodão e outras mercadorias manufaturadas e, por êsse meio, aliviar um pouco a pressão do bloqueio continental francês (24), mas pressionaram, também, o Brasil, a partir de 1817, no sentido de abolir um dos mais importantes setores de sua economia, o tráfico de escravos. O estudo agora clássico de Manchester (25), sôbre as relações anglo-brasileiras, delineia como o interêsse português, tão poderoso polìticamente no tráfico de escravos, cerceava os esforços dos diplomatas britânicos para obrigar Dom Pedro I a eliminá-lo. A entrosagem entre a política e a economia do Primeiro Reinado na obra de Manchester, British Preeminence in Brazil, é suplementada por uma análise de E. Galles sôbre a cena econômica brasileira em 1828, abrangendo a rivalidade comercial franco-britânica, os produtos de exportação e as manufaturas importadas, os regulamentos tarifários assim como fatôres econômicos que influiam no reconhecimento do Brasil (26). Algumas das implicações

(23). - Alberțo Carlos de Araújo Guimarães, "Silva Lisboa", Segundo congresso de história nacional, Anais, III, 681-763; Hélio Viana, "Retificaçōes à bibliografia do Visconde de Cairú", Primeiro Congresso de História da Bahia, Anais, V, 323-324. Reimpressão dos trabalhos mais importantes de Silva Lisboa pode ser encontrado em Memória dos beneficios politicos do govêrno đe El-Rey nosso senhor D. João VI. 2a. ed., Rio de Janeiro, 1940, e na cuidadosa edição de Princípios de economia política. Introdução por A. Amoroso Lima. Anotações por Nogueira de Paula. Rio de Janeiro, 1956. Silva Lisboa, Princípios de direito mercantil (Lisboa, 1789) também merece edição crítica. Para visão mais crítica desenvolvida sôbre o regime Joanino pelo diretor do Correio Brasiliense, ver Jane Herrick, "The Reluctant Revolutionist. A Study of the Political Ideas of Hipólito da Costa, 1774-1823", Américas, VI (outubro, 1950), 171-181.

(24). - Cf. Artigo de Herbert Heaton sôbre Luccock, "A Merchant Adventurer in Brazil", Journal of Economic History, VI (maio, 1946), 1-23 e a edicaão recente de John Luccock, Notas sôbre o Rio de Janeiro e partes meridionais do Brasil. São Paulo, 1942.

(25). - Alan K. Manchester, British Preeminence in Brazil. Its Rise and Fall, Chapel Hill, 1933.

(26). - Edouard Galles, Du Brésil, ou observations générales sur le commerce et Ies douanes de ce pays. Paris, 1928, foi editado por Guilherme Deveza em "Um precursor do comércio francês no Brasil", Revista de História, III (julho-setembro, 1952), 75-92; III (outubro-dezembro, 1952), 353- 
mais latas sôbre a influência econômica britânica no Brasil foram esboçadas por Gilberto Freire em Os Inglêses no Brasil (27) ponto de vista de um historiador social sôbre aculturação, baseado em material proveniente de inglêses residentes no Brasil ou viajantes. (28) e cuidadosa seleção de jornais contemporâneos.

\section{III}

A ausência de síntese autorizada, notada no tratamento recente da história do Brasil relativa às primeiras três déca-

372; IV (janeiro-março,1953), 123-142; V (outubro-dezembro, 1954), 283306 e VI (janeiro-junho, 1955), 209-238. Carlos da Silveira, "Guaratinguetá de 111 anos atrás. Breve relatório das manufaturas em 1825", RAMSP, III (XXX, 1936), 91-118, descreve a produção local do artezanato no interior.

(27). - Os inglêses no Brasil. Aspectos da influência britânica sôbre a vida, a paisagem e a cultura do Brasil. Prefácio de $O$. T. de Souza. Rio de Janeiro, 1948.

(28). - Ediçōes brasileiras de viagens do princípio do século XIX, enriqueceram a historiografia brasileira dos últimos anos. Representam um monumento ao nacionalismo cultural da época. o que se segue é apenas uma indicação de trabalhos existentes. Para uma excelente introdução ver de Rodolfo Garcia, "História das explorações científicas", Instituto Histórico e Geográfico Brasileiro, Dicionário histórico, geográfico e etnográfico do Brasil (2 vols., Rio de Janeiro, 1922), I, 856-910), esp. 881 ff., sua "Maria Graham no Brasil", Biblioteca nacional, Anais, LX (1938), 7-71, e seu Dos viajantes do Brasil. (1817-1821, 1819-1821). Rio de Janeiro, 1925; M. C. van Eschewege, Diário de uma viagem do Rio de Janeiro à Vila Rica na capitania de Minas Gerais no ano de 1811. São Paulo, 1936; John Mawe, Viagens ao interior do Brasil, principalmente aos distritos do ouro e dos diamantes. Rio de Janeiro, 1944; Maurício Rugendas, Viagem pitoresca através do Brasil. São Paulo, 1949; Rubens Borba de Moraes, "Introdução ao estudo da obra de Saint-Hilaire", RAMSP, V (LIII, 1939), 99-112. Augusto de Saint-Hilaire, Viagens ao Rio Grande do Sul, 18201821. São Paulo, 1949. Viagens pelas províncias do Rio de Janeiro e Minas Gerais. São Paulo, 1938. Segunda viagem ao interior do Brasil. Rio de Janeiro, 1937 e sua Viagem às nascentes do Rio São Francisco e pela provincia de Goiás. Rio de Janeiro, 1937; Herbert Baldus, "A viagem pelo Brasil de Spix e Martius", RAMSP (LXIX, 1940), 131-146 e J. B. von Spix e C. F. P. von Martius, Viagem pelo Brasil, 4 vols.., Rio de Janeiro, 1938; Hércule Florence, Viagem fluvial do Tietê ao Amazonas de 1825 a 1829. São Paulo, 1942.

Com referência à contribuição dos artistas para o nosso conhecimento do Brasil desde o período ver, J. F. de Almeida Prado, Tomas Ender, pintor austríaco na côrte de $D$. João VI no Rio de Janeiro. Um episódio da formação da classe dirigente brasileira, 1817-1818. São Paulo, 1955 e 0 Velho Rio de Janeiro através das gravuras de Tomas Ender. São Paulo, 1957. Sôbre a missão francesa de 1816, ver A. d'E. Taunay, A missão artística de 1816. Rio de Janeiro, 1912, Francisco Marques dos Santos, "O ambiente artístico fluminense à chegada da missão francesa em 1816", Revista do serviço do patrimônio histórico nacional (RSPHAN), V (1941), 213-240, Adolfo Morales de los Rios, Grandjean de Montigny e a evolução da arte brasileira. Rio de Janeiro, 1941, e Jean Baptiste Debret, Viagem pitoresca e histórica ao Brasil, 2 vols., São Paulo, 1940. 
das do século XIX, repete-se na historiografia das duas décadas seguintes que começam com a abdicação de Dom Pedro I em 1831 e terminam com a repressão à Revolução Praieira de Pernambuco em 1849. Em muitos aspectos nossa compreensão a respeito dos nove anos da Regência, quando os conservadores vão assumir gradativamente o contrôle do govêrno, e dos movimentos revolucionários ocorridos nessas duas décadas não progrediu desde a publicação, há um século, de duas peças de brilhante literatura polêmica da autoria de dois escritores políticos: uma pelo jornalista Justiniano José da Rocha, subvencionado pelos conservadores, outra pelo advogado dos liberais, Francisco de Sales Tôrres Homem. Talvez haja mais do que uma simples coincidência no fato de ambos terem sido reimpressos recentemente com ensaios introdutórios (29). Admitir que uma síntese dessas décadas complicadas e relativamente pouco investigadas exige maior número de estudos monográficos, levanta apenas a questão do como e porque as poucas monografias existentes se tenham limitado a focalizar um punhado de personalidades e impressos, evitando, com raras exceções, analisar os partidos conservadọ e liberal, suas plataformas, assim como o grupo de interêsse que um e outro representavam (30). Nesse sentido a geração de historiadores do após-guerra pode ter refletido a ausência, em sua própria época, de partidos políticos claramente definidos.

$\mathrm{Na}$ opinião de J. José da Rocha, as fôrças liberais que forçaram Dom Pedro a abdicar em 1831, dividiram-se após a vitória. O deslocamento de monarquistas constitucionais para o lado dos grupos ultra-conservadores forçou os elementos liberais da Regência a bandearem-se desde 1836 para a oposição. Incapazes de controlar o govêrno, recorreram à violência. A exposição de Sales Tôrres Homem concordava, em essência,

(29). $\rightarrow$ Por Raimundo Magalhães Júnior, Três panfletários do segundo reino (São Paulo, 1956), 3-43 (sôbre Sales Tôrres Homem), 127.159 (sôbre J. J. da Rocha). Para outras ediçōes ver Justiniano José da Rocha, "Açăo, reação, transação", RIHGB, 219 (abril-junho, 1953), 206-238 e Timandro (pseudônimo de Sales Tôrres Homem), "O libelo do povo", Revista do Brasil, 3a. fase, Ano III, n.o 19 (janeiro de 1940), 61-96. Sôbre os laços conservadores de Rocha, ver José Antônio Soares de Souza, "Cartas de Justiniano José da Rocha ao Visconde do Uruguai", RIHGB, 220 (julhosetembro, 1953), 339-348.

(30). - Hélio Viana, "A pequena imprensa da regência trina permanente (18311835)", RIHGB, 179 (1943), 17-101 e 180 (1943), 63-114); Nelson Werneck Sodré, "A pequena imprensa na regência do Império", RAMSP (CXXXIV, 1950, 69-89. 
com esta análise; entretanto, criticava os conservadores ao atacar a instituição que êstes sustentavam com vigor, isto é, a monarquia. A seus olhos a ameaça às instituições políticas brasileiras era a expansão do poder autocrático ("capricho dinástico") nas mãos de $\mathrm{D}$. Pedro II, ao terminar a regência em 1840. Seu Libelo do povo foi um protesto liberal contra as medidas arbitrárias tomadas pela Corôa ao reprimir a revolta liberal de Pernambuco em 1848, e visando a impedir a realização da promessa da independência, isto é, a "renovação social e política". As biografias das principais figuras da Regência, tais como Bernardo de Vasconcelos, Feijó e Evaristo da Veiga, da autoria de O. Tarquínio de Sousa, embora úteis, não modificaram substancialmente, assim como não o fizeram suas análises dos golpes de 1831 e 1840, êsses pontos de vista anteriores.

$\mathrm{Na}$ realidade, apenas quanto ao tratamento dado às eclosões revolucionárias através do Brasil, na primeira metade do século XIX, adiantaram-se os historiadores do após-guerra aos seus predecessores. Estes, em especial os que escreveram sob a influência do Império, ou da nostalgia do Império, estavam naturalmente interessados em realçar a "lei e ordem" que o Império interpunha como barreira salutar às desordens das repúblicas sul-americanas, considerando as revoltas brasileiras como maléficos levantes da soldadesca. Historiadores mais recentes já as encaram com mais simpatia. Dois fatôres, pelo menos, podem explicar o interêsse dos historiadores do após-guerra pelas revoluções da primeira metade do século XIX. Primeiro, o desêjo de comemorar o centenário dêsses acontecimentos com publicações de coleções de documentos e, se. possível, com algumas análises. Em segundo lugar, a instabilidade que o Brasil sentia entre 1920 e 1930, quando esta inquietação latente explodiu em diversas revoluções: 1922, 1924, 1930,1932, 1935 e 1937. O grande número de estudos publicados na Europa e América para comemorar a revolução de 1848 ilustra, aliás; o mesmo fator.

Um levantamento das recentes coleções de documentos e análises em tôrno dos movimentos revolucionários a partir de 1789 , sugere a hipótese de que fôssem indícios de um conflito entre aquêles que desejavam a independência e os que apoiavam o sistema colonial, entre os brasileiros e os portuguêses, entre os vários matises de liberais e conservadores e entre grupos da classe média urbana e a oligarquia rural. Aparentemente as conspirações de Minas (1789), da Bahia 
(1798) (31) e Pernambuco (1817) visavam mais a reformar do que a destruir o regime colonial. Posteriormente, quando o nôvo regime implantado pela Independência sob $D$. Pedro I, demonstrou ser um abrandamento apenas nominal do absolutismo, do contrôle central, e da influência administrativa e econômica portuguêsa, as revoltas tornaram-se freqüentemente movimentos anti-monárquicos, anti-coloniais e republicanos. Dirigiam-se contra a sobrevivência do absolutismo real e contra os comerciantes portuguêses como grupo econômico dominante nos portos. No Nordeste agravou-se a situação com o declínio da economia açucareira; as restrições impostas pelos inglêses contra o açúcar produzido pelo trabalho escravo e as revoltas de escravos, que contavam com a participação de grupos numerosos de artífices e mulatos livres.

Em suas investigações sôbre as raízes das revoltas, os historiadores modernos, ao contrário dos antigos, deram mais atenção à inquietação econômica e social do que às diferentes políticas ou fatôres de personalidades. E' o que talvez se encontre na introdução de Maximiniano Machado a uma reedição da História da revolução de Pernambuco em 1817 (1917) de Muniz Tavares, obra clássica sôbre o assunto (32). Assevera Machado que Muniz Tavares, um participante, ignorou como causas da revolução a desorganização financeira do regime joanino e os favores dispensados a eminentes refugiados portuguêses cujo sustento significava uma sangria para o Tesouro. A interpretação de Vicente Licínio Cardoso, também mostra como o tom anti-escravagista da revolta assustava os senhores de escravos que constituiam o elemento político mais poderoso de Pernambuco, que haviam importado da costa africana entre 1800 e 1817 aproximadamente 130.000 negros (33). O exame destas teses será provàvelmente facilitado pela publicação recente de seis volumes de documentos sob a direção de José Honório

(31). - Ver Mário Behring, "Introdução", e documentos em "A Inconfidência da Bahia em 1798', Biblioteca nacional, Anais, XLIII-XLIV (1920-1921), 1-11, 85, 225, e em Biblioteca nacional, A Inconfidência da Bahia: Devassas e sequiestros. Rio de Janeiro, 1931; Luís Viana Filho, "Homens e coisas da revolução baiana de 1798", Terceiro congresso de história nacional, Anais, IV, 641-663; Afonso Rui de Souza. A primeira revolução social brasileira. São Paulo, 1942.

(32). $\rightarrow$ Francisco Muniz Tavares, História da revolução de Pernambuco em 1817. 3a. ed., Oliveira Lima, ed., Recife, 1917.

(33). - À margem da história do Brasil (Livro póstumo), (São Paulo, 1933), 171. 
Rodrigues, incluindo o artigo de autoria dêste sôbre a historiografia e biografia do movimento (34).

No relato de Soares Brandão referente à segunda revolta pernambucana, a Confederação do Equaidor (35) de 1824, o levante de 1817 é visto como uma preparação de terreno para a insurreição mais séria ocorrida sete anos depois. Houve continuidade de elementos participantes, pois que Frei Caneca (36), figura chave de 1817, também reaparece no levante de 1824, e assim também Manuel de Carvalho Paes de Andrade, que passou nos Estados Unidos parte - quatro anos - do período entre as duas revoluções. Para provar que o movimento pernambucano de 1824 foi mais do que uma quartelada sem planejamento, como o afirmavam Varnhagen e Pereira da Silva, defensores do Império, Soares Brandão assevera que suas raízes podem ser encontradas nos reformadores brasileiros dos fins do século XVIII, nos exemplos das revoluções americana e francesa e nos contactos com responsáveis pelo levante português de Gomes Freire ocorrido em 1817. Em 1817 os revolucionáitios propuseram a emancipação progressiva dos escravos, a liberdade de imprensa e a tolerância religiosa. Em 1824 advogaram a República, e a abolição do tráfico. Soares Brandão conclui que ambas as revoltas foram condenadas ao fracasso por incompetência militar, e embora sugira ter a promessa de emancipação dos escravos sido, talvez, o fator que envenenou o movimento, aos olhos dos plantadores nordestinos individados aos agentes e exportadores portuguêses.

Os "brasilianistas" não investigaram com o mesmo cuidado tôdas as rebelióes ocorridas nos vinte anos seguintes à abdicação de Dom Pedro (37). Nem as insurreições do Pará

(34). - "Revoluçāo de 1817", Biblioteca nacional, Documentos históricos, CICIX (1953-1955, resenhado por George Boehrer, em HAHR, XXXVII (novembro de 1957), 509-511. Há também documentos disponíveis na Biblioteca Nacional, Anais, LXXI (1951). Em edição de cartas do historiador brasileiro, Capistrano de Abreu, Rodrigues observa que Capistrano sentiu que o levante de 1817 e as insurreições subseqüentes foram manifestações de independência mais significativas que a Inconfidência Mineira. José Honório Rodrigues, ed., Correspondência de Capistrano de Abreu (3 vols.; Rio de Janeiro, 1954-1956), I, XIVII-XLVIII.

(35). - Ulisses de Carvalho Soares Brandão, Pernambuco d'outrora; a Confederaçāo do Equador. Pernambuco, 1924.

(36). - Cf. Mário Melo, Frei Caneca. Recife, 1933.

(37). - Como estudo geral das origens separatistas dêsses bevantes, ver Agenor de Roure, "Os pródromos do federalismo. Idélas, projetos e programas dos partidos", RIHGB, tomo especial, Congresso internacional de história da América, Anais (9 vols., Rio de Janeiro, 1925-1930), VI, 453-530 e Percy A. Martin, "Federalism in Brazil", HAHR, XVIII (maio, 1938), 143-163. Thomas W. Palmer Jr., analisou os breves esforços para 
e Amazonas, a Cabanagem (1833-1836) (38), nem a guerra civil republicana e federalista do Rio Grande do Sul (1835-1845) (39), foram objeto da mesma atenção prodigalizada à Sabinada da Bahia (1837), à revolução de 1842 em Minas Gerais e São Paulo e à terceira revolta que se verificou em Pernambuco num prazo de meio século, a chamada Revolução Praieira de 1848-1849.

O movimento ocorrido na Bahia, com o nome de Sabinada, recebeu considerável atenção através da publicação de uma série de artigos interpretativos, relatos de participantes ou testemunhas visuais, além de duas análises (40). Viana Filho, em sua literária popularização, tentou colocar no contexto o fermento revolucionário brasileiro a partir da malfadada Francezia baiana surgida em 1789 . Segundo mostrou Braz do Amaral, grande número de baianos lutou contra a recalcitrante guarnição portuguêsa durante durante nove meses em 1821, prelúdio sangrento para a separação da mãe-pátria e bem menos suave do que o movimento de independência em São Paulo e Rio em 1822 (41). Este conflito tornou os baianos e nortistas em geral mais suscetíveis às manifestações do absolutismo imperial e mesmo à uma eventual recolonização portuguêsa, quando Dom Pedro I dissolveu a Assembléia Constituinte de 1823. Como resultado, muitos partidários da Independência converteram-se ao republicanismo e ao federalismo. O Ato Adicional e a eleição de assembléias provinciais (1843) foram, segundo Viana Filho, concessões imperiais ao sentimento regional durante a fase da reforma democrática da Regência entre 1831 e 1836. Depois da explosão da guerra civil no Rio Grande do Sul (1835), um dos seus líderes, Bento Gonçalves, fugiu para a Bahia

descentralizar o contrôle político na década de 1839 em "A Momentous Decade in Briazilian Administrative History, 1831-1840", HAHR, XXX (maio, 1950), 209-217.

(38). - Basílio de Magalhães, "A cabanagem", Estudos de história do Brasil (São Paulo, 1940), 203-243.

(39). - Basílio de Magalhães, "Guerra dos Farrapos", ibid., 165-202; Alfredo Varela, História da Grande Revoluçāo: o ciclo farroupilha no Brasil. Pôr to Alegre, 1933; Dante de Laytano, História da república riograndense, 1835-1845. Pôrto. Alegre, 1936 e Instituto Histórico do Rio Grande do Sul, Congresso sul-riograndense de História, Anais, 3 vols. Pôrto Alegre, 1935.

(40). - Bahla. Publicaçōes do Estado da Bahia, A revolução de 7 de novembro de 1837 (Sabinada). 3 vols., Bahia, 1937-1945; José Wanderley de Araújo Pinho, "A Sabinada", Revista do Instituto Histórico da Bahia, CVI (1930), 635-793; Luís Viana Filho, A Sabinada: a república baiana de 1837. Río de Janeiro, 1938

(41). - Brás do Amaral, Ação da Bahia na obra da independência nacional. Babla, 1992. 
onde com seus seguidores juntou-se a republicanos expatriados, franceses e inglêses. Infelizmente, a análise que Viana Filho faz da revolta e de seu fracasso ressente-se da falta de acuidade demonstrada nas secções introdutórias. Depois da Marinha Imperial transportar tropas, bloquear a Bahia e esmagar a revolta, firmando-se assim como o instrumento de centralização mais efetivo da monarquia - e depois de Sabino Vieira ser aprisionado na residência do Cônsul francês, o leitor permanece sem uma idéia clara do programa e dos defensores da Sabinada.

As origens e os objetivos da primeira e maior revolta suscitada depois de coroado Dom Pedro II, a revolução de 1842, permanecem igualmente enigmáticos. No estudo, talvez mais esclarecedor de todos (42), Aluísio de Almeida apresenta um grupo de liberais brasileiros das classes altas, temerosos do conservantismo da última Regência que, em 1840, empurrara para a coroação um ansioso Dom Pedro apenas para ver seus centralistas conservadores colhêr o fruto de seus esforços. $\mathrm{O}$ ministério conservador criou em novembro de 1841 um Conselho de Estado vitalício designado para aconselhar o jovem Imperador. O código criminal da Primeira Regência (1832), obra dos liberais, foi enfraquecido, reduzindo-se a autoridade dos funcionários provinciais e distritais. Eliminaram-se os juizes locais eleitos, substituídos por autoridades policiais e judiciais (juízes de direito), designados pelo Govêrno Imperial e encarregados de supervisionar o progresso eleitoral. Para assegurar a predominância dos interêsses dos fazendeiros nas eleições, as exigências fiscais ao direito de voto foram elevadas para 400 mil réis nas cidades grandes, 300 nas pequenas e 200 nos distritos rurais. Os comerciantes deviam possuir renda mais de duas vêzes superior à dos plantadores a fim de tornar-se menos efetiva, como Aluísio de Almeida sugere, a sua oposição à prorrogação do acôrdo comercial feito com a Grã-Bretanha (novembro de 1842), segundo o qual esta mantinha sua posição de nação mais favorecida.

Quando o Imperador dissolveu a recém-eleita Câmara dos Deputados, onde os liberais tinham maioria, e convocou no-

\footnotetext{
142). - Aluísio de Almeida (pseudônimo), A revoluçăo liberal de 1842. Rio de Janelro, 1944 que pode ser comparada à narrativa mais antiga de Eduardo de Menezes, A revoluçáo mineira de 1842. Juiz de Fora, 1913. Para opıniāo contemporânea ao fato e publicađa pela primeira vez em 1844, há de José Antônio Marinho, História do movimento político que no ano de 1842 teve lugar na provincia de Minas Gerais. Lafayette, Minas Gerais, 1939. Ver também Lúcio José dos Santos, "A revolução de 1842 em Minas Gerais", RIHGB, 180 (julho-setembro, 1943), 117-166.
} 
vas eleições, a "Sociedade de Patriarcas Invisíveis" do Rio enviou instruções aos seus filiados provinciais de Minas Gerais e São Paulo para iniciarem a revolução. Uma proclamação atacou as "oligarquias turbulentas e opressoras" que cercavam o. Imperador, embora o lema dos revolucionários fôsse: "A Santa Religião, Sua Magestade, o Imperador e a Constituição". O Govêrno Imperial enviou por mar tropas leais - desta vez já em barcos a vapor - do Rio de Janeiro a Santos, para abafar a rebelião em São Paulo. No relato de A. de Almeida não está esclarecida a razão de se ter travado a batalha mais encarniçada no Vale do Paraíba, que entrava então no "boom" cafeeiro.

Enquanto a revolta liberal de 1842 se desenvolvia entre as elites brasileiras divididas, a segunda e última grande revoita, da década de 1840, extravasou os limites de classes. A Praieira pernambucana, de 1848-1849, marcou o fim de mais de uma geração de surtos revolucionários no Brasil e foi o terceiro levante violento ocorrido em Pernambuco desde 1817. Num contexto mais ampio dos acontecimentos, a Praieira pode ser considerada, embora na escala menor do Brasil de 1848, a última tentativa antes de 1889, de levar o movimento da Independência de 1821 e sua seqüência, à abdicação de Pedro I em 1831, até ao seu desfêcho republicano e federalista. Todos os elementos encontrados esporàdicamente nas revoluções antecedentes aparecem simultâneamente na Praieira: conflito entre o antigo regime moribundo e o pré-liberalismo de 1850 , sentimento nacionalista ou nativista dirigido contra burocratas e comerciantes portuguêses, choque entre os pequenos burgueses e os interêsses "feudais" dos fazendeiros senhores de escravos, seccionalismo e republicanismo como defesa de uma área econômica em declínio contra uma monarquia cujos interêsses econômicos e políticos ameaçavam negligenciar os problemas regionais.

O relato penetrante de Amaro Quintas sôbre a Revolução Praieira pernambucana desenterra um levante local até então olhado como luta política entre oligarcas liberais e conservadores e trata-o como um microcosmo das fôrças econômicas e sociais no Brasil após um quarto de século de independência. Como as publịcações referentes às revoluções precedentes, Quintas preparou seu trabalho para uma celebração do centenário desta revolução e conseguiu audiência mais vasta por intermédio da Revista de História (43), recentemente funda-

(43). - Amaro Quintas, “O sentido social da revolução praieira. Ensaio de intẹpretação*, Revista de História, IX (julho-setembrọ̣, 1954), 131-178. 
da. Baseado no uso diligente de jornais, narrativas de testemunhas visuais e material documentário, o trabalho de Quintas ilumina o papel do peripatético revolucionário brasileiro Antônio Borges da Fonseca, que começou sua carreira política como editor "jacobino" no Rio de Janeiro em 1830 e assim continuou até a morte em 1872 (44). A Praieira teve a sina de tôdas as agitações que a precederam. De fato, com seu colapso, extinguiram-se as clarinadas do Partido Liberal no Império.

$\mathrm{Na}$ éra de realismo político que uniu, por trás do Império, os Liberais e Conservadores, éra que se iniciou logo após a revolução Praieira e perdurou até a Guerra do Paraguai, os liberais fizeram uma série de acomodações. Alguns, como Borges da Fonseca, permaneceram intransigentes, e sempre sob vigilância policial (45). Outro, Sales Tôrres Homem ("o demagogo desencantado"), depois de abraçar a monarquia tornou-se deputado, ministro da Fazenda, senador, diretor do Banco do Brasil, chargé d'affaires em Paris, e Visconde de Inhomerim (46). Outro ainda, o liberal mineiro Ferreira de Rezende

Sumário da edição original, o sentido social da revolução praieira (Recife, 1946), foi publicado por Nogueira de Matos, "Algumas observaçōes sôbre a revolução praieira", Revista de História, I (janeiro-março, 1950), 83-93. Outras publicaçōes concernerites à Praieira incluem: o Progresso. Revista social, literária e cientifica. Reedição do govêrno do Estado de Pernambuco como parte do programa das comemorações do centenário da Revolução Praieira; Prefácio de Amaro Quintas. Recife, 1950. José Almansur Hađdad, "Castro Alves e a revolução praieira", Revista de História, IV (janeiro-março, 1953), 211-222; Barbosa Lima Sobrinho, "A Revolução praieira", RHHGB, 201 (outubro-dezembro, 1948), 102-119; Walter Lopes de Rezende, “A insurreiçāo de 1849 na província do Espirito Santo", Quarto Congresso de História Nacional, Anais, XIII, 69-90. Os artigos sôbre a Revolução Praieira na Revista do arquivo público (Recife), ano 3 , n.o 5 (1948) não foram consultados.

Sôbre o impacto europeu em Pernambuco na década de 1840, ver o relatório de Louís Vauthier em Serviço do Patrimônio Histórico e Artístico Nacional, Diário íntimo do engenheiro Vauthier, 1840-1846 Prefácio e notas de Gilbento Freire. Rio de Janeiro, 1940, e de Freire, Um engenheiro francês no Brasil: com prefácio do prof. Paul Arbousse-Bastide. Rio de Janeiro, 1940. Indício da repercussão em alguns setores do Brasil das notícias sôbre as erupções revolucionárias da Europa em 1848 encontra-se em Magalhães Júnior, ed., Três panfletários, 51-60 e José Wanderley de Araújo Pinho, Cotegipe e seu tempo. Primeira fase, 1815-1867 (São Paulo, 1937), 140.

(44). - Ver Hélio Viana, "O repúblico Antônio Borges da Fonseca". Cultura política, XV (maio, 1944), 151-190.

(45). - Joaquim Nabuco, Um estadista do Império. Nabuco de Araújo. Sua vida, suas opiniōes, sua época (2 vols., 2a. ed., São Paulo, 1936, I, 272-278).

(46). - Otávio Tarquínio de Sousa, introdução ao "Libelo do povo", Revista do Brasil, 3a. fase, n. 19 (janeiro, 1940), 6162 e Floriano Tôrres Homem, "Francisco de Sales Tôrres Homem, visconde de Inhomerim", Terceiro Congresso de História Nacional, Anais, VI, 85-165. 
que escolheu o melhor dos dois mundos, comprou uma fazenda com seus escravos e mudou-lhe o nome para "Filadelfia": lembrança da "república para a qual sempre vivi sem esperanças" (47).

E' óbvio que a historiografia moderna referente à primeira metade do século XIX tornou inadeqüada a antiga preocupação com personalidades e políticos. As investigações futuras terão que levar em conta o problema da escravidão e do tráfico de escravos e suas repercussões sôbre o jôgo político, o papel dos burocratas e comerciantes portuguêses na economia e administração de uma nação recém-emancipada; o impacto de uma imprensa, prolífera e vociferante - comumente desenfreada - sôbre os grupos urbanos, e a influência dos acontecimentos europeus e norte-americanos sôbre as ocorrências brasileiras. Em suma, os historiadores terão de comparar a observação de Nabuco ao dizer que as revoluções brasileiras eram apenas "ondulações" (48) originadas em Paris, com o que èstamos começando a aprender sôbre a realidade interna na época.

(47). - Francisco de Paula Ferreira de Rezende, Minhas recordaçōes. Prefácio đe Otávio Tarquínio de Sousa (Rio de Janeiro, 1944), 433. Um aspecto da moderação ou acomodação política destas duas décadas posteriores a 1850 - o homogêneo fundamento cultural e social da burocracia do Império e do Parlamento - está ainda por ser examinado. Nos vinte anos que vão de 1830-1850 o Império integrou no judiciário, no sistema policial, na burocracia e Parlamento, muitos jovens nascidos em Portugal ou pelo menos educados em Coimbra. Pela sua origem de berço, educação e antecedentes sociais, eram ou ràpidamente tornaram-se conservadores monárquicos juntamente com os graduados pela escola de direito de Olinda. Solteiros, considerados "bons partidos", casaram-se cona representantes da oligarquia rural. Como o mostram suas biografias recentemente publicadas, constituiram, na maturidade, a elite do Império na éra da conciliação ou pelo menos uma década após. Cf. Wanderley Pinho, Cotegipe e seu tempo. Primeira fase, 1815-1867. São Paulo, 1987; Albino José Barbosa de Oliveira, Memórias de um magistrado do Império... por seu bisneto Américo Jacobina Lacombe. Sāo Paulo, 1943; José Arftônio Soares de Souza, Um diplomata do Império. Barão da Ponte Ribeiro. São Paulo, 1952; Renato de Mendonça, Um diplomata na corte da Inglaterra. O barão de Penedo e sua época. São Płaulo, 1942; Luís da Câmara Cascudo, 1938; Hélio Viana, Visconde de Sepetiba. Petrópolis, 1943; João Craveiro Costa, o visconde de Sinimbú. Sua vida e sua atuzção na política nacional (1840-1899). São Paulo, 1937; Henrique Carneiro Leāo Telxeira Filho, "O Conselheiro Jerônimo José Teixeira Júnior (Visconde de Cruzeiro)", RIHGB, 164 (1931), 357-388; Wanderley Pinho, "Visconde Taunay", ibid., 181 (1943), 5-43; Heitor Moniz, "Estadistas do Império", ibid., 97 (1925), 109-136; Batista Pereira, Figuras do Imp6́rio e outros ensalos. São Paulo, 1944. Há breves biografias laudatórias sobre personagens eminentes do Império na obra recentemente reeditada de Sebastiāo A. Sisson, Galeria dos brasileiros ilustres (Os contemporáneos), 2 vols., Rio de Janeiro, 1948.

(48). $\rightarrow$ Nabuco, Um estadista, I, 72. 


\section{IV}

A julgar pelo volume de publicações concernentes ao apogeu do Segundo Reinado, isto é, às quatro décadas posteriores à última das maiores insurreições, a de 1848-1849, essa fase foi investigada com muito maior interêsse pelos "brasilianistas" modernos do que o demonstrado por outras fases do desenvolvimento brasileiro no século XIX. Assim como as análises dos movimentos revolucionários anteriores a 1850 foram provàvelmente inspiradas pela agitação das décadas de 1920 e 1930, a historiografia recente sôbre o Segundo Reinado não pode ser divorciada das vicissitudes da República. Mais significativo talvez, é o fato de se discernirem duas correntes historiográficas, uma conservadora, outra liberal ou revisionista. Vistos dêsse ângulo, pode-se dizer que os historiadores freqüentemente perscrutam o Segundo Reinado para defender ou atacar o que veio depois, isto é, a República inaugurada em 1889.

A interpretação da escola conservadora ou pró-Império dominou, com pequena oposição, o campo dos "brasilianistas", de 1889 a meados de 1920. Foram expoentes dêste grupo o Barão do Rio Branco, Mossé, Rocha Pombo, Nabuco e Oliveira Lima (49), hàbilmente secundados pela maioria dos colaboradores do volume comemorativo do Centenário do nascimento de Dom Pedro II (1925), preparado pelo Instituto Histórico e Geográfico Brasileiro (50). Os membros desta escola nasceram e criaram-se sob o Império permanecendo muitos fiéis ao passado regime dentro do Instituto Histórico - tão caro a D. Pedro II - e das suas nublicações. Esses historiadores não aprovavam a República em razão de sua política que consideravam dominada pela imoralidade, o empreguismo, a carência de tradições: para fazer valer sua crítica exaltavam, em contraste, o Império e o Imperador. Ao focalizar Dom Pedro II, fustigavam, de fato, a República, acenando para a ordem aparente que havia

\footnotetext{
(49). - Há um artigo do Barão do Rio Branco em Emile Levasseur, ed., Le Brésil. Paris, 1889; Benjamin Mossé; Dom Pedro empereur du Brésil. Paris, 1889; José F. da Rocha Pombo, História do Brasil. 10 vols., Rio de Janeiro, 1906; Manuel de Oliveira Lima, "Formation historique de la nationalité brésilienne". Paris, 1911, e Nabuco, "Um estadista do Império".

(50). - RIHGB, 152 (1925). Ver também RIHGB, tomo especial, Contribuições para a biografia de $D$. Pedro II (Rio de Janeiro, 1925), $I_{x}$ parte 1a. João Camilo de Oliveira Tôrres, A democracia coroada (Teoria política do Império do Brasil), Rio de Janeiro, 1957, reafírma hàbilmente a posição conservadora; Gilberto Freire é um convertido recente é escola pró-imperial. Ver seu New $W$ orld in the Tropics. The Culture of Modern Brazil (New York, 1959), esp. cap. VII.
} 
no Império, o respeito pelas autoridades legalmente constituídas, a moderação e o tradicionalismo, a aristocracia e o paternalismo. Olhando o passado, sentindo a nostalgia do Império, esqueciam suas fraquezas e enroupavam o regime com a benignidade de sua figura mais atraente: o "Imperador Filósofo" Dom Pedro II. Criando uma imagem paternal do Imperador, não tentou a escola conservadora isolá-lo do liberalismo e humanitarismo do século XIX. Afirmavam ter êle condenado o tráfico de escravos e a instituição da escravidão e que a política partidária e a imaturidade da população brasileira impuseramlhe uma intervenção, que nunca desejara na vida política do país.

Até o balanço dos fatos feito recentemente por Haring, alguns "brasilianistas" dos Estados Unidos, como P. A. Martin e M. W. Williams aceitavam sem críticas êste ponto de vista (51). Williams no seu Dom Pedro, o Magnânimo interpreta a reação dos políticos brasileiros à "dissolução arbitrária da câmara dos deputados" por Dom Pedro como o resultado de um mal entendido real ou fictício, por parte dos políticos, a respeito do "espírito de fairplay que animara o Imperador". Considera Dom Pedro como o "fator principal e inconteste do progresso brasileiro" (isto é, do desenvolvimento econômico) com participação em tudo quanto foi realizado. Sua oposição à idéia de emancipação sem compensações, esposada pela Princesa Isabel ("...mas se eu tivesse estado lá, o que foi feito não o teria sido") é explicada como "resultado de um sentimento passageiro". Fruto de erudição laboriosa repetidamente atenta a minúcias insignificantes, a biografia do Imperador escrita por Williams resume-se na sua frase final: ". . . sua integridade, magnanimidade, piedade compreensiva e bondade cristã fizeram dêle uma das personalidades mais notáveis dos tempos modernos" (52). Dom Pedro, o Magnânimo representa uma síntese do ponto de vista e do tratamento dispensado pelos panegiristas do Império, pois realça quase exclusivamente os fenômenos políticos, assim como a pessoa, os interêsses intelectuais e a modelar vida familiar do Imperador (53).

\footnotetext{
(51). - Percy A. Martin, "Causes of the Collapse of the Brazilian Empire", HAHR, IV (fevereiro, 1921), 4-48; Mary Wilhelmine Williams, Dom Pedro The Magnanimous. Second Emperor of Brazil. Chapel Hill, 1937. Cf. A. K. Manchester, "Dom Pedro Segundo, the Democratic Emperor", em L. F. Hill, ed., Brazil (Berkeley, 1947), 35-59.

(52). - Op. cit., 135, 228, 286, 382.

(53). - Tenta-se, aqui, apenas uma seleção das numerosas publicações sôbre $D$. Pedro II e sua época. Em adição às publicações já citadas, há o relato mais balanceado de Heitor Lira, História de D. Pedro II. 3 vols., São Pau-
} 
O ponto de vista conservador não foi sèriamente contestado até meados da década de 1920. Então, o grupo de historiadores liberais ou pró-republicanos se atirou à defesa de um regime republicano que fôra manipulado no nível nacional e local pela união das oligarquias que defendiam desesperadamente um oneroso programa de garantia dos preços do café e mostravam-se incapazes de abafar incessantes revoluções. Diagnosticavam como congênita a fraqueza da República herdada do Império. Examinando o Império encontravam um Imperador medíocre, prêso à rotina, um burocrata por excelência, cuja incapacidade tornou inevitável a proclamação da República (54). Revisionistas mais que denunciadores, preocuparam-se com os aspectos econômicos e sociais do Império que os historiadores de antes evitaram ou trataram superficialmente. Procuraram as bases econômicas e sociais das éras mais pacíficas do Império, a éra de "conciliação" ou de compromisso político que se estendeu do fim do tráfico de escravos (1850) até a eclosão da Guerra do Paraguai (1865), e estudaram com novas perspectivas, à escravidão e a abolição; a emigração e o início da industrialização, e as origens do movimento republicano. Suas publicações, abrangendo as três últimas décadas do Império, sugerem que a inabilidade do govêrno imperial para solucionar o problema da moderniza-

lo, 1938-1940. Em poucas páginas Cristiano B. Ottoni, O Advento da República no Brasil. (Rio de Janeiro, 1890). 108-116, oferece uma síntese igualmente equilibrada sôbre o Imperador.

Śôbre a controvérsia de D. Pedro II com o seu genro francês, ver de Alberto Rangel, Gastão d'Orleans, o último Conde d'Eu. São Paulo, 1933. Há também um volume de Rangel sôbre a educação de Pedro. A educação do príncipe. Esbôço histórico e crítico sôbre o ensino de $D$. Pedro II. Rio de Janeiro, 1945.

São raras as publicaçōes documentárias. A mais notável inclui: "Inventário dos documentos do arquivo da casa imperial do Brasil existentes no Castelo d'Eu", Biblioteca Nacional, Anais, LIV-LV e reimpressa pelo Ministério de Educação em 2 vols., Rio de Janeiro, 1939; Ministério das Relaçōes Exteriores, Publicaçōes do conselho de estado e do consultor do ministério dos negócios estrangeiros. Rio de Janeiro, 1942, sumário de relatórios sôbre política externa.

Ver também Wanderley Pinho, Cartas do Imperador D. Pedro II ao barão de Cotegipe. São Paulo, 1933, e Alcindo Sodré, ed., Cartas de Dom Pedro II à condessa de Barral. Rio de Janeiro, 1956. Para conhecimento de ponto de vista iconoclástico sôbre a correspondência de D.. Pedro com a Conđessa de Barral, ver Raimundo Magalhães Júnior, ed., D. Pedro II e a condessa de Barral, através da correspondência intima do Imperađor anotada e comentada. Rio de Janeiro, 1956.

(54). - Gilberto Freyre em sua fase mais antiga e iconoclástica comparou uma vez D. Peđro a uma "espécie de Rainha Vitória de calças, apenas mais poderoso". "Social life en Brazil in the Middle of the Nineteenth Century", HAHR, V (1922), 611. 
ção tornou o regime moribundo e abriu caminho para a República.

Os preceitos capitais da escola revisionista foram ministrados antes por dois ensaios interpretativos do que por grandes obras de síntese (55). Vicente Licínio Cardoso escrevendo em 1920, partiu da premissa de que os relatos tradicionais. sôbre o Império, os de Rio Branco, Mossé, João Ribeiro, Rocha Pombo, Oliveira Lima e Nabuco, eram superficiais, uma vez. que não lograram entrever com bom êxito o que encobria a fachada parlamentar dos dois partidos monárquicos: o Liberal e o Conservador. Evitaram problemas de primordial importância, tais como o tráfico de escravos e a escravidão, o papel do govêrno na economia, e o desenvolvimento do comércio e indústria em favor de uma crônica estéril das manobras intra e inter-partidárias. Estavam, portanto, segundo Licínio Cardoso, cegos às origens do movimento republicano. Para êles a República de 1889 não tinha origens nativas. Gilberto Amado, autor de outro ensaio revisionista, sustentou que as instituições parlamentares brasileiras eram apenas reflexo pálido das inglêsas e francesas, uma vez que os políticos não percebiam "certas peculiaridades da cena local e suas condições típicas". Gilberto Amado sustentou que o atraso econômico encorajou o. analfabetismo, assim como a inércia política, e impôs a um Imperador intelectualizado, mas medíocre, responsabilidades que êle não estava a altura de suportar. Licínio Cardoso e Gilberto Amado assinalaram o fato de Dom Pedro II não ter estimulado a emigração como meio de superar a emergente crise do trabalho escravo, preferindo agir como um Mecenas de artistas pobres, porém bem dotados, quando deveria estar lutando. pelo desenvolvimento econômico, pela educação pública e pelas escolas técnicas.

O ensaio de Licínio Cardoso vai além da contribuição de outros escritores ao ligar a éra do acôrdo político ou conciliação (1853-1864) às repercussões políticas que resultaram do término do tráfico de escravos (56). De acôrdo com Licínio Car-

(55). - Vicente Licínio Cardoso, "A margem do Segundo Reinado", $\mathbf{A}$ margem da história do Brasil (Livro póstumo), 121-215, publicado pela prineira. vez em RIHGB, 98 (1925), 1039-1087; Gilberto Amado, "As instituiçōes políticas e o meio social no Brasil” em Antônio Carneiro Leão et al., A margem da história da república (Idéias, crenças e afirmaçōes), (Rio de Janeiro, 1924), 57-78.

(56). - Cf. Caio Prado Júnior, "Segundo reinado", Manual de estudos brastleiros, 433-439; Robin A. Humpherys, "Monarchy and Republic", em H. A. Livermore, ed., Portugal and Brazil. An introduction (Oxford, 1953), 301-320; Manuel de Oliveira Lima, O império brasileiro. São Paulo, 1927; 
doso, a necessidade de sobreviver, ou o denominado realismo político, forçaram Dom Pedro II e os líderes do partido Conservador à conciliação com os elementos da oposição liberal. Quando suprimiram com relutância o tráfico de escravos (1850) (57), os conservadores eliminaram de seu partido os elementos retrógrados mais intransigentes; os remanescentes do partido Conservador engendraram, então, um acôrdo operante com uma parcela (chimangos ou moderados) dos Liberais. Éste partido tinha sido enfraquecido por seus laços ideológicos com - Liberalismo avançado dos grupos revolucionários. suprimidos nas décadas de 1830 e 1840, particularmente com o radicalismo do levante pernambucano de 1848-1849. Por meio de astuciosa distribuição de títulos de nobreza e nomeações para cargos públicos, o Imperador e os conservadores moderados descobriram que êsses Liberais compartilhavam de sua reprovação ao republicanismo e confiavam numa monarquia constitucional ordeira, assim como partilhavam da repugnância moral por uma instituição que do ponto de vista econômico, ainda era, todavia, inevitável: a escravidão. Enquanto a intervenção política do Imperador, através do poder moderador, foi considerada equitativa pelos Liberais, funcionou suavemente a estrutura parlamentar. Os "brasilianistas" não consideraram esta tese. A verdade é que os mais radicais, ou liberais históricos, por alguma razão ainda não esclarecida nas sínteses de Licínio Cardoso e Gilberto Amado, ou em outras

Nelson Werneck Sodré, Panorama do segundo império,. São Paulo, 1939; Joāo Capistrano de Abreu, Ensaios e estudos (3a. série. Rio de Janeiro, 1938), 114-130.

(57). - Para discussão geral sôbre, o comércio ver A. K. Manchester, British Preeminence in Brazil; Maurício Goulart, Escravidão Africana no Brasil (Das origens à cessação do tráfego), (São Paulo, 1949), esp. 219-279; Ciro T. de Pádua, "Um capítulo da história econômica do Brasil", RAMSP, XI (C, 1945), 135-190 e A. d'E. Taunay, "Subsídios para a história do tráfego africano no Brasil", Museu Paulista, Anais, X, parte 2, 5-311, esp. 274-311, que inclui o livro de contas (1818-1830) de um traficante de escravos aos plantadores e mostra a relação entre o tráfego e a expansão do café. Sôbre a abolição do tráfico ver Jane Elizabeth Adams, "The

, Abolition of the Brazilian Slave Trade", Journal of Negro History, $X$ (outubro, 1925), 607-737, excelente artigo baseado nos documentos oficiais britanicos; Lawrence F. Hill, "The Abolition of the African Slave Trade to Brazil", HAHR, XI, (maio, 1931), 169-197, e Percy A. Martin, "Slavery and abolition in Brazil", ibiơ., XIII (maio, 1933), 151-196. O papel desempenhado pela Grā-Bretanha foi revisto em Antônio Ferreira Cesarino Júnior, "A intervenção da Inglaterra na supressão do tráfico de es. cravos africanos para o Brasil", Revista do Instituto Histórico e Geográfico de São Paulo, XXXIV (1938), 147-166, em William L. Mathieson, Great Britain and the Slave Trade. Londres, 1949. Os dois últimos itens foram fornecidos por Peter R. Faber, antigo estudante. 
narrativas, começaram a reexaminar o papel do Imperador depois de ter êste dissolvido uma câmara recém-eleita controlada pelos Liberais (1863), nomeando um ministério Conservador que procedeu à eleição de uma câmara Conservadora. Liberais históricos, como Tavares Bastos, Teófilo Ottoni e Tito Franco de Almeida, aos quais em trabalhos recentes se tem dado alguma atenção, acreditavam que o "poder moderador" do Imperador era um "poder pessoal" mal disfarçado.

Faceta curiosa da escola revisionista moderna é a ausência de crítica erudita documentada sôbre o Segundo Reinado ou sôbre o Imperador. Assim como o Libelo do Povo de Sales Tôrres Homem, reeditado recentemente, sustenta-se como o panfleto mais importante contra a centralização do poder nas mãos dos Conservadores na década de 1830 e 1840, do mesmo modo contentaram-se os críticos do Imperador em reeditar os ataques de Tavares Bastos, Ottoni e Tito Franco, os três maiores porta-vozes da oposição à monarquia constitucional brasileira na década de 1860 quando se desmoronou a conciliação. Ainda que sejam apenas reedições, fornecem uma análise dos entimentos políticos sob o Imperador, análise que a historiografia moderna têm evitado.

Teófilo Ottoni, cuja Circular apareceu em 1860 e foi reeditada em 1930 (58), pertenceu à corrente radical liberal do princípio do século XIX que parece ter fluído de maneira subterrânea na década da conciliação. Segundo Pinheiro Chagas, seu biógrafo recente (59), Ottoni era amigo do jornalista politicamente moderado das décadas de 1820 e 1830, Evaristo da Veiga. Teófilo Ottoni apoiava as restrições liberais ao exercício do poder moderador em 1834 e sentiu-se ultrajado quando os Conservadores centralizaram de nôvo o poder político em 1841. Em 1859 e nos anos subseqüentes, o Imperador preteriuo várias vêzes ao escolher para senador por Minas nomes menos prestigiosos do Partido Conservador, das listas tríplices apresentadas pelo eleitorado mineiro. A Circular de Ottoni atacou a "oligarquia" conservadora, seu domínio sôbre a política imperial e sôbre a da conciliação, assim como a intervenção excessiva do Imperador no sistema parlamentar bi-partidário do país. A reeleição de Teófilo Ottoni em 1860 seguiu-se à

(58). - Teófilo Ottoni, Circular dedicada aos senhores eleitores de senadores pela provincia de Minas Gerais. Prefácio por Alberto da Cunha Horta. 4a. ed., Rio de Janeiro, 1930 .

(5:). - Paulo Pinheiro Chagas, Teófilo ottoni, ministro do povo. Rio de Janeiro, 1943. Cf. Basilio de Magalhães, Teófilo Ottoni. Rio de Janeiro, 1945. 
publicação da Circular e parece marcar o ressurgimento dos elementos históricos dentro do Partido Liberal, dividindo-o em duas alas antagônicas ao final da Conciliação e significando o primeiro passo para a criação do Partido Republicano em 1870.

Sete anos depois da Circular de Ottoni, apareceu crítica menos polêmica e mais analítica do sistema imperial, feita por Tito Franco de Almeida em biografia reeditada recentemente, Conselheiro Francisco José Furtado. Biografia e estudo da história política contemporânea (60). Ostensivamente, biografia de membro do Conselho de Estado Imperial, era, na realidade, um panfleto político mal disfarçado, publicado no áuge da luta entre as duas facções do Partido Liberal. Tito Franco situou o tema principal da política brasileira após 1840 no aumento crescente do poder executivo, o "imperialismo" do govêrno pessoal de Dom Pedro. No primeiro estágio dêsse desenvolvimento (1840-1853) os partidos Liberal e Conservador lutavam entre si enquanto o poder executivo crescia. No segundo estágio (18531866), o poder executivo, segundo Tito Franco, "corrompeu" os partidos, ao passo que no terceiro estágio (depois de 1866) o poder executivo e o Partido Conservador governaram o Império, comprando a oposição com a renda crescente das exportações do café.

Tavares Bastos em A Província, reeditada em 1937 (61), apresentou, enfeixando uma década de renascente liberalismo no Brasil, a argumentação mais convincente em prol da reforma e não da revogação do sistema imperial. A Província encarava o fenômeno de centralização política dentro do contexto internacional, como o atestam as citações de Tocqueville, da Revue des deux monldes, da Anti-Slavery Reporter e da American Freedman's Union. À maneira utilitarista e "Benthoniana", Tavares Bastos participa das preocupações de Teófilo Ottoni e Tito Franco a respeito do contrôle do govêrno sôbre a

(60). - Sảo Paulo, 1944. As notas à margem escritas por D. Pedro II, freqüentemente citadas como exemplo de sua imparcialidade e perspicácia, encontram-se nessa edição como também em Max Fleuiss, Dom Pedro Segundo (Rio de Janeiro, 1940), 94-132.

(61). - Aurealiano Cândido Tavares Bastos, A provincia: estudo sôbre a descentralização no Brasil. 2a. ed., São Paulo, 1957. Exposição igualmente valiosa com referência às suas idéias pode ser encontrada em suas Cartas do solitário. Rio de Janeiro, 1862, o vale do Amazonas. Rio de Janeiro, 1866 e Os males do presente e as esperanças do futuro. São Paulo, 1939. Parte dêste material encontra-se em Luís Pinto, Idéias e pensamentos de Tavares Bastos. Rio de Janeiro, 1946. Há também a biografia por Carlos Pontes, Tavares Bastos. São Paulo, 1939 e um pequeno esbôço feito por Rodrigo Otávio, Figuras do Império e da República. Rio de Janeiro, 1944. 
vida nacional como faceta da eterna luta do indivíduo contra o Estado em expansão, da liberdade contra a fôrça. As instituições parlamentares brasileiras eram artificiais, insistia. Requeriam centralização política baseada em uniformidade nacional impossível numa nação composta de elementos tão diversos como o Brasil. Insistir em que tal centralização ocorria por não estar o povo brasileiro preparado para se governar por si mesmo, e alegava que isso conduzia apenas ao maior despotismo tal como acontecera na Espanha, onde o povo não obtinha preparação alguma para a liberdade. Esposava como "doutrina liberal" - eleições diretas, mandatos temporários e não vitalícios para os senadores, serviço militar obrigatório, sistema judicial independente, abolição do Conselho de Estado e restrições do poder moderador - recordava aos conservadores que o liberalismo no Brasil não era pura fantasia, tinha raízes profundas em sua história da década de 1830 quando a fôrça dessas correntes profundas forçara o Ato Adicional criando as legislaturas provinciais, eleição dos membros da Regência, e a abolição do Conselho de Estado. Batia-se finalmente pela extinção gradual da escravidão, não de sua abolição imediata.

E' lamentável que êstes panfletos políticos tenham sido reimpressos sem comentário crítico e que os "brasilianistas" tenham deixado de esmiuçar sua tese comum, a que Ottoni chamou o "demônio orgânico do sistema", isto é, a centralização política do Império. Tendo em vista as preocupações do século XIX com problemas políticos e constitucionais, tudo nos leva a afirmar ser a centralização, provàvelmente, apenas uma faceta do fenômeno mais complexo. Talvez o ataque à centralização fôsse ao mesmo tempo dirigido contra a subordinação do govêrno imperial aos interêsses locais, sua negligência pelo desenvolvimento econômico local, a drenagem da renda local para reforçar uma política imperial formulado no Rio de Janeiro em favor dos interêsses do mais poderoso sustentáculo do Império, a oligarquia dos senhores de escravos. O total das realizações e fracassos do Império somados por Haring, sugere negligência do regime em resolver problemas econômicos e sociais básicos que os historiadores modernos começam agora a examinar (62).

Se os latino-americanistas devem as revisões da evolução do Segundo Reinado feitas por Licínio Cardoso e Gilberto Amado às crises da Primeira República, no final da década de 1920,

(62). - C. H. Haring, Empire in Brazil. A New World Experiment with Monarchy (Cambridge, Mass, 1958), 165. 
devem igualmente à crise mundial de 1929 o esclarecimento, - se bem que muitas vêzes indireto, de aspectos econômicos fundamentais do Segundo Reinado e suas repercussões sociais. O colapso temporário do setor de exportação da economia brasileira, o abandôno do programa de valorização do café, e a super-produção açucareira, provocaram entre os "brasilianistas" um exame crítico e lúcido das origens e da evolução da economia nacional, e seu papel na economia mundial. Caio Prado Júnior em sua interpretativa História Econômica do Brasil (63), elaboração de seus primeiros estudos sôbre a história econômica colonial e a dos primeiros períodos nacionais do ponto de vista marxista, tentou relacionar o problema da escravidão, o da monocultura e a política, mas suas páginas não documentadas e sua escassa bibliografia não mencionam estudos monográficos recentes que tratam do maior setor econômico do Brasil do século XIX, a agricultura de exportação e problemas correlatos a respeito de trabalho e transporte, e as primeiras tentativas de diversificação econômica através da industrialização.

O motivo de ter sido possível aos gabinetes imperiais, tanto conservadores como liberais, negligenciar a questão da escravidão durante vinte e um anos depois do término do tráfico de escravos foi tocado apenas tangencialmente pelas publicações recentes sôbre escravidão e emigração. Uma segunda edição do estudo clássico de Perdigão Malheiro, A escravidão no Brasil, publicado pela primeira vez em 1866 (64), exemplifica a aproximação jurídica à instituição mais unificadora do Império, isto é, seu sistema de trabalho. Com respeito à história intelectual do Império, revela o ponto de vista de um liberal esclarecido pouco antes do fervor emancipador e abolicionista transformar-se de uma questão acadêmica, como era para Malheiro, em um problema prático. O estudo de Evaristo de Morais (65) sôbre a escravidão recorda

(6己). - São Paulo, 1945, especialmente o capitulo, “o Império escravocrata e a aurora burguesa (1850-1889). Idêntica influência sôbre os brasilianistas exercem João F. Normano, em Brazil. A Study of Economic Types. Chapel Hill, 1935. Para um "modêlo" de economista relativo a estrutura econômica do Segundo Reinado ver Celso Furtado, A economia brasileira (Contribuição à análise do seu desenvolvimento), Rio de Janeiro, 1954, 83-94, e sua sugestiva elaboração, Formação econômica do Brasil, (Rlo de Janetro, 1959), 129-190. Um bom instrumento bibliográfico foi fornecido por Tom B. Jones, et al., A Bibliography on South American Economic Affairs: Articles in Nineteenth Century Periodicals (Minnesota, 1955), 58-89.

(64). - A escravidão no Brasil. Ensaio histórico-jurídico-social. 2 vols. Rio de Janelro, 1944. Contém apêndice documentário sôbre o períođo, 1831-1864.

(65). - Evaristo de Morais, A escravidáo africana no Brasil (Das origens a extinção). São Paulo, 1933. Cf. H. C. Leão Teixeira Filho, "A atitude par. 
que Malheiro, juntamente com outros liberais, opunha-se à medida tampão (1871) como solução à emancipação proposta pelo ministério conservador Rio Branco. Não surpreende que a discussão sôbre a escravidão empreendida por Malheiro após o término do tráfico de escravos revele uma atitude complacente para com a condição dos escravos do Brasil, complacência essa reiterada em análises recentes de historiadores americanos (66). Só o artigo de Artrur Ramos (67) desafiou êste ponto de vista róseo, e apenas estudos futuros sôbre as condições nas fazendas ou do ponto de vista dos escravos poderão elucidar a questão. Outros fatôres, parecem, também, ter contribuido para essa complacência e resignação entre os membros dos partidos monárquicos. O exame feito por Nícia Vilela Luz (68) sôbre o abolicionismo em São Paulo salienta o fato de que na fase inicial do movimento os fazendeiros paulistas eram favorecidos pela crise que lavrava entre os senhores de escravos nortistas, que, em face da insolvência de plantações de algodão $\epsilon$ açúcar viam-se obrigados a vender seus escravos aos sulistas fazendeiros de café de São Paulo e Rio de Janeiro em luta com a falta de braços. Além disso, como provam estudos sôbre a experiência de colonização realizada por Vergueiro nos meados do século em São Paulo, os fazendeiros de todo - Brasil, até 187.0, não viam na imigração européia uma alternativa viável à substituição do trabalho escravo.

Só há pouco a emigração para o Brasil atraiu a atenção dos eruditos (69). Os historiadores e os sociólogos em geral têm ficado impressionados, e com razão, pelo tamanho, organização e facilidade aparente de integração das ondas de emigração que verteram no Brasil milhões de europeus entre 1880 e 1920 (70). Só recentemente surgiu uma respeitável análise

\footnotetext{
lamentar de Teixeira Júnior em 1870", Terceiro congresso de história nacional, Anais, II, 497-535.

(66). - Cf. M. W. Williams, "The Treatment of Negro Slaves in the Brazillan Empire, A Comparison with the United States". Journal of Negro History, XV (1930), 313-336, H. B. Alexander, "Brazilian and United States Slavery Compared", ibi., VII (1922), 349-364, Frank Tannenbaum, Slave and Citizen. New York, 1947, e P. A. Martin, "Slavery and Abolition in Brazil", HAHR, XIII (maio, 1933), 151-196.

(67). - "Castigos de escravos", RAMSt, IV (XEVIII, 1938), 79-104.

(68). - Nícia Vilela Luz, "A administraçăo provincial de Săo Paulo em face do movimento abolicionista", Revista de administração, II (dezembro, 1948), 80-100.

(69). - Nótável exceção a essa generalização é Robert F. Foerster, The Italian Emigration of Our Times (Cambridge, Mass., 1919), 279-319, que aborda ràpidamente o período pré-1889.

(70). - Cf. o Boletim do serviço de imigração e colonização, n.o 2 (1940), a Revista de imigração e colonização (1940) e T. Lynn Smith, Brazil: People and Institutions. Baton Rouge, 1946 e 1954.
} 
estimativa do esfôrço humano, da adaptação e integração dos emigrantes na cultura brasileira, fornecida por Willems a propósito dos emigrantes alemães (71). Relato de há um século, de autoria de Tschudi, acentua que a condição dos imigrantes europeus no Brasil era particularmente difícil. Num extrato de seu trabalho original, intitulado Viagem às províncias do Rio de Janeiro e São Paulo (72) torna-se claro que o imigrante foi contratado para substituir os escravos nas áreas rurais. Emigrando na esperança de tornar-se propridtáio, viam;se submetidos a uma subserviência patronal que não combinava com seus anseios. Estes e outros aspectos da emigração são explorados por Sérgio Buarque de Holanda na edição das memórias de Davatz, crônica da vida nas plantações de Vergueiro; e, também, pelo ensaio de Carneiro sôbre a imigração (73).

Nicolau Vergueiro contratou e transportou em 1847, para sua fazenda em São Paulo, diversas dezenas de emigrantes suíços e alemães, incluindo-se entre êles Davatz. Sob um sistema de "parceria" os emigrantes eram alojados em casebres onde podia abrigar-se uma família e tinham permissão para plantar os alimentos necessários ao consumo pessoal. Os colonos concordavam em reimbolsar as despêsas feitas pelo patrão. Após diversos anos de recriminação mútua, reuniram-se numa revolta de pequenas proporções e abandonaram a fazenda de Vergueiro. Os colonos, insistiu Davatz, consideravam a "parceria" apenas estágio imediato para a posse da terra, enquanto Vergueiro pretendia transformá-la em arranjo permanente. Em biografia recente, escrita por Djalma Forjaz (74), Vergueiro é mostrado como fazendeiro fora do comum, pois, tinha si-

\footnotetext{
(71). - Emílio Willems, "Immigrants and Their Assimilation in Brazil", em T. Lynn Smith e Alexander Marchant, eds., Brazil. Portrait of Half a Continent. New York, 1951, 209-226, sintese que deve ser lida paralelamente à sua Assimilação e populaçōes marginais no Brasil, Estudo sociológico dos imigrantes germânicos e seus descendentes. São Paulo, 1941 e ao seu trabalho mais desenvolvido Aculturação dos alemães no Brasil. São Paulo, 1946. Cf. Reinhard Maack, "The Germans of South Brazil: A German View', Quaterley Journal of Inter-American Relations, I (julho, 1939), 5-21, "Die deustche literatur ueber die deustche einwanderung und siedlung in Sued Brasilien", HLAS: 1938, 399-417 e de Alexander Marchant, "Writings in English, French, Italian and Portuguese concerning the German Colonies in Southern Brazil", ibi., 418-341.

(72). - Johann J. von Tschudi, Viagem às províncias do Rio de Janeiro e são Paulo. São Paulo, 1954.

(73). - Thomaz Davatz, Memórias de um colono no Brasil (1850). Tradução, prefácio e notas de Sérgio Buarque de Holanda. São Paulo, 1941. J. Fernando Carneiro, "História da imigraçāo no Brasil. Uma interpretação", Boletím Geográfico, VI (dezembro, 1948), 1009-1044. Ver também. sua Imigração e colonização no Brasil. Rio de Janeiro, 1949.

(74) . - Djalma Forjaz, O senador Vergueiro, São Paulo, 1924.
} 
do deputado de São Paulo às Côrtes Portuguêsas, depois da revolução liberal do Pôrto (1820), apoiara a monarquia constitucional quando Dom Pedro I abdicou (1831), assim como a malograda revolta liberal de 1842 . Teve visão e coragem para fazer a experiência de uma forma de labor que constituiria transição entre a escravidão e o trabalho assalariado. Quando os fazendeiros paulistas souberam das dificuldades de Vergueiro, evitaram seu exemplo para impedir que os escravos fôssem inoculados pelo virus da independência. As autoridades suíças e alemãs, em represália, suspenderam as emigrações para o Brasil com o fim de evitar que se cometessem indignidades contra seus compatriotas.

O prefácio cuidadoso de Sérgio Buarque de Holanda às memórias de Davatz, comparando a experiência de Vergueiro e o "back-ground" da emigração brasileira em 1857, conclui que as dificuldades dos emigrantes se deviam ao serem êstes provenientes do proletariado urbano da Europa Central, e da incompatibilidade entre as técnicas agrícolas européias baseadas na conservação do solo e uma agricultura tropical onde as florestas virgens tinham de ser abatidas; havia ainda o conflito religioso entre os imigrantes protestantes e os brasileiros católicos, e, finalmente, a falta de higiene e de cuidados sanitários dos teuto-suíços numa terra onde o clima tropical tornava os banhos freqüentes um imperativo. Os fazendeiros confederados que fugiram do Sul dos Estados Unidos depois da Guerra Civil, na opinião de Buarque de Holanda, contribuiram mais para a agricultura de São Paulo - por exemplo, mecanização incipiente - do que seus precursores teutosuíços. Está ausente da análise de Buarque de Holanda o conflito, na época, entre a imigração para estabelecimento em "colônias" nas fronteiras e a destinada a substituir os escravos nas plantações. Carneiro em sua interpretação, concluiu que, depois de 1842, os fazendeiros fizeram pressão sôbre o govêrno no sentido de vender terras públicas por preços elevados para forçar os imigrantes a "alugar o seu trabalho". Pode-se concluir, por meio dêstes estudos, que a experiência de Vergueiro foi lógica, porém prematura. Só depois da década de 1880, quando o fim do prolongamento da escravidão pareceu impossível, o govêrno provincial de São Paulo e os lavradores aceitaram a grande vaga de imigração de europeus do sul, mas em seus próprios têrmos, isto é, as "parcerias".

Sem dúvida, o crescimento econômico notável do Brasil nas décadas de 1850 e 1860 , quando o aumento da exportação 
de café do centro-sul obscureceu a crise provocada pelo cultivo e elaboração relativamente ineficientes do açúcar no nordeste, diminuiu também a pressão sôbre os estadistas imperiais no sentido de acharem soluções aceitáveis para os problemas econômicos e sociais. Entretanto, por volta de 1930, uma crise econômica generalizada e a insolvência dos lavradores de café do centro-sul, assim como dos exportadores e refinadores de açúcar no nordeste, forçaram os govêrnos federal e estaduais, assim como as agências para-estatais, a subvencionar investigações sôbre a história dos setores açucareiros e cafeicultores da economia nacional. Indiretamente, estas investigações lançaram alguma luz sôbre aspectos inexplorados da história do Segundo Reinado.

Entre os mais notáveis dêstes estudos estão os de Milliet (75) e Taunay (76), encomendados, ambos, por agências regionais e federais. Milliet analisou a expansão do cultivo do café em direção ao oeste, através de São Paulo, a partir de 1836, e correlacionou, por tabelas, o crescimento da população com o do café e outros produtos em zonas sucessivas. O trabalho de Milliet estabeleceu a perspectiva geral para a crônica do café escrita por Taunay em numerosos volumes. Os seis volumes que tratam do café no Império, assim como os oito sôbre a éra republicana, oferecem "close-ups" da economia e sociedade conjuntamente extraídos de relatórios anuais provinciais e imperiais, descrições de viajantes brasileiros e estrangeiros e material manuscrito correlato, aparecendo muitos itens com transcrição literal. Os volumes estão curiosamente aliviados do aparato erudito. Não há rodapés, bibliografia, índice analítico, muitas fontes são descritas inadeqüadamente e citadas com imprecisão. Os latino-americanistas devem ao Departamento Nacional do Café essa mina de informações, pois o trabalho de Taunay foi pago por linhas. Outros estudos monográficos sôbre a história econômica do Império - a análise pormenorizada feita por Canabrava, do "boom" algodoeiro paulista (1861-

\footnotetext{
(75). - Sérgio Milliet, Roteiro do café. Análise histórico-demográfica da expansão cafeeira no Estado de São Paulo. São Paulo, 1938, reeditado no ano seguinte como Roteiro do café e outros ensalos. Contribuição para o estudo da história econômica do Brasil. A mudança do título é significativa.

(76). - Afonso d'E. Taunay, História do café no Brasil. 15 vols., Rio de Janeiro, 1939-1943, e uma abreviação onde falta a miríade de detalhes do original, Pequena história do café no Brasil. Rio de Janeiro, 1945. Ver também, José Teixeira de Oliveira, Vida maravillhosa e burlesca do café. 2a. ed., Rio de Janeiro, 1942 e Roberto Simonsen, "Aspectos da história econômica do café", Terceiro Congresso de histórỉa nacional, Anais, IV, 213-305.
} 
1875), a análise de De Carli sôbre a economia açucareira fluminense, o volume de Poliani sôbre a Sociedade Nacional de Agricultura do Império e o artigo de Almeida sôbre a importância de Sorocaba na época anterior às estradas de ferro quando mulas de carga e seus tropeiros eram a espinha dorsal do transporte (77) - evitaram as armadilhas em que caiu Taunay, limitando o espaço, seja geográfico, seja cronológico; abrangido pelos seus respectivos tópicos.

Sôbre a área cafeeira sulista que floresceu e declinou no Segundo Reinado, no Vale do Paraíba, não apareceu ainda síntese definitiva. Monografias de comunidades ou áreas selecionadas salientaram, entre outras coisas, o fato dos fazendeiros do Vale do Paraíba não desejarem ou não poderem preparar o braço livre que substituisse o escravo tradicional e, como seus colegas do Norte, os plantadores da cana de açúcar que vendiam seus escravos aos cafeicultores do Sul, queixavam-se da mudança dos tempos e esperavam patèticamente que o Imperador resistisse à emancipação ou à abolição. Quando as terras ficaram velhas para o plantio do café, êstes proprietários e seus descendentes enfrentaram ou a pobreza honrosa, ou a emigração para as terras virgens ou para as capitais. do Rio de Janeiro e São Paulo (78). Como foi mostrado em muitos artigos, estas capitais, depois de 1850, tornaram-se o centro das finanças, do comércio externo e interno, do transporte e da administração pública, tôdas essas atividades escorando-se no cultivo, processamento e exportação do café e na. importação e distribuição dos artigos de primeira necessidade e luxo (79). Famílias de fazendeiros abandonaram as sonolen-

(77). - Alice Canabrava, o desenvolvimento do algodão ha província de São Paulo, 1861-1875. São Paulo, 1951; Gileno de Carli, Evolução do problema canavieiro fluminense. Rio de Janeiro, 1942; Luís Marques Poliano, A sociedade nacional de agricultura. Resumo histórico. Rio de Janeiro, 1945; Aluísio de Almeida, "Os caminhos do sul e a feira de Sorocaba", RIHGB, 186 (janeiro-março, 1945), 96-173.

(78). - S. J. Stein, Vassouras, A Brazilian Coffee County, 1850-1900. Cambridge, Mass., 1957, que pode ser comparado com o estudo sociológico de Lucila Hermann, Evolução da estrutura social de Guaratinguetá num período de trezentos anos, Revista de administração, II (março-junho, 1948), 53-199, e Maria Isaura Pereira de Queiroz, "A estratificaçāo e a mobilidade social nas comunidades agrárias do Vale do Paraíba entre 1850 e 1888", Revista de História, I (abril-junho, 1950), 195-218. Há uma breve visão contemporânea das plantações de café no século XIX em Herbert Huntingdon Smith, Uma fazenda de café no tempo do Imprério. 2a. ed., Rio de Janeiro, 1941.

(79). - Para o estudo da vida nas principais cidades no apogeu e nos últimos dias do Império, ver Wanderley Pinho, Salóes e damas do segundo reinado. São Paulo, 1942, que descreve com nostalgia os "bons tempos" através daqueles que podiam melhor aproveitá-los - altos funcionários. 
tas cidades do interior, não mais visitadas pelas companhias de teatro e ópera, preferindo o ruído e amenidades sociais e culturais da vida metropolitana, como já o haviam feito, no Nordeste, seus êmulos sociais.

Nos críticos anos da década de 1930, quando apareceram estudos sôbre a história e economia cafeeira no centro-sul do Brasil, historiadores e novelistas simultâneamente começaram a estudar em cheio o ciclo açucareiro do Nordeste desde a sua origem colonial até o presente. Gilberto Freyre, em Casa Grande e Senzala (80) procurou as raízes do Brasil moderno no passado colonial, e duas décadas após seu aparecimento torna-se difícil recapturar seu impacto sôbre o pensamento sociológico brasileiro na época. Infelizmente êste impacto, tanto no Brasil como no exterior, tendem a obscurecer o significado de Sobrados e Mucambos (publicado dois anos após) e de outros trabalhos publicados subseqüentemente por Gilberto Freyre nos quais desvia sua atenção para a história social do Brasil no século XIX, analisando os efeitos da influência européia e norteamericana no Nordeste brasileiro (81). $\mathrm{Na}$ realidade a própria

públicos, fazendeiros, homens de negócios e classes profissionais. Colhida nas páginas das colunas sociais dos jornais do Rio de Janeiro é de Francico Marques dos Santos, "A sociedade fluminense em 1852", Estudos Brasileiros, III (maio-junho, 1941), 201-289. Para conhecimento da vida nas classes mais humildes ver a novela picaresca de Manuel Antônio de Almeida, Memórias de um sargento de milícias. São Paulo, 1941, e de Joaquim Manuel de Macedo, Memórias da Rua do Ouvidor. Prefácio e notas de Jamil Almansur Haddad. São Paulo, 1952, que deve ser lido paralelamente ao artigo de Astrogildo Pereira, "Romancistas da cidade: Macedo, Manuel Antônio e Lima Barreto", Revista do Brasil, 3a. fase, IV (maio, 1941) 26-59), e de Raymond $S$. Saéers, The Negro in Brasilian Literature (New York, 1956), 173-178, 218-221. Há também o romance de Aluísio Azevedo, A Brazilian Tenement. New York, 1921, isso sem mencionar as recentes versões para o inglês das novelas de Machado de Assis.

Richard Morse nos oferece uma ampla visão do desenvolvimento de São Paulo em From Community to Metropolis. Gainesville, 1958, que deve ser lida junto com a História e tradiçōes đa Cidade de São Paulo, de Ernâni Silva Bruno. 3 vols., Rio de Janeiro, 1853. Ver também de Odilon Nogueira de Matos, "A Cidade de São Paulo no século XIX", Revista de História, VI (janeiro-junho, 1955), 89-126 e de Emília Nogueira, "Alguns aspectos da influência francesa em São Paulo na segunda metade do século XIX", ibid., IV (outubro-dezembro, 1953), 317-342.

(80). - Gilberto Freyre, Casa Grande e Senzala. Formação da família brasileira sob o regimen da economia patriarcal. Rio de Janeiro, 1934. Apareceu uma oitava eđição em 2 vols., Rio de Janeiro, 1954, cuja crítica foi feita por Emílio Willems em HAHR (agôsto, 1955), 410-411.

(81). - Sobrados e mucambos. Introdução à história da sociedade patriarcal no Brasil. Decadência do patriarcado rural e desenvolvimento do urbano. São Paulo, 1936. Também 2a. ed., 3 vols., Rio de Janeiro, 1951. Os outros trabalhos incluem: Nordeste, Aspectos da influência da cana sôbre a vida e a paisagem do Nordeste do Brasil. Rio de Janeiro, 1937, e o já citado Os inglêses no Brasil (1948) e Um engenheiro francês no 
obra de Gilberto Freyre presta-se como medida da influência da "nova história" - fusão de história, economia, antropologia e sociologia - exercida sôbre êle durante o período em que residiu e estudou nos Estados Unidos, na década de 1920. Em artigo publicado em 1922 (82) esboçou o retrato do Brasil de 1850 quando a economia mundial do século XIX estava por transformar a velha ordem brasileira. O artigo prenunciava Sobrados e Mucambos, um estudo da urbanização no Nordeste brasileiro sob o Império, que está a merecer uma edição americana tão completa como a de The Masters and the Slaves. Segundo a análise de Gilberto Freyre, explica-se o gradual empobrecimento das famílias numerosas ou clãs dos engenhos de açúcar pelo término do tráfico de escravos, pela estagnação tecnológica da economia açucareira e expansão do cultivo da beterraba na Europa, pela comercialização da agricultura, pelas irresistíveis atrações da vida cosmopolita e: seu alto custo. Desalojados de seus engenhos pela evicção, encontraram segurança econômica na burocracia em expansão, ṇo Segundo Reinado e na República, como testemunham recentes histórias sôbre as plantações e diários de senhores de engenho (83) .

E' difícil determinar o motivo porque os "brasilianistas" da década de 1930 se voltaram para a história agrícola e social do século XIX deixando de examinar com igual interêsse a história financeira e industrial do Segundo Reinado (84).

Brasil (1940), e "Casas de residência no Brasil. Introdução". RSPHAN, VII (1943), 92-127. E' tempo de se ir além de Lewis Hanke em sua apreciação "Gilberto Freyre: Brazilian Social Historian", Quaterly Journal of Inter-American Relations, I (julho, 1939), 24-44.

(82). - "Social Life in Brazil in the Middle of the Nineteenth Century", HAFr, V (1922), 597-630.

(83). - Júlio Belo, Memórias de um senhor de engenho. Prefácios de Gilberto Freyre e José Lins do Rêgo. Rio de Janeiro, 1938. 2a. ed., Rio de Janeiro, 1948; Felix Cavalcanti de Albuquerque Melo, Memórias de um Cavalcanti. Trechos de livro de assentos de... (1821-1901) escolhidos e anotados pelo seu bisneto Diogo de Melo Menezes. São Paulo, 1940; Wanderley Pinho, História de um engenho do Recôncavo. Maotim, Caboto, Freguesia, 1552-1944. Rio de Janeiro, 1946; João Albuquerque Maranhão, História da indústria açucareira no Nordeste. o papel social de Catende. Rio de Janeiro, 1949. Para uma síntese ver Manuel Diegues Júnior, o banguê nas Alagoas. Traço da influência do sistema econômico do eqgenho do açúcar na vida e na cultura regional. Prefácio de Gilberto Freyre. Rio de Janeiro, 1949.

(84). - Uma das poucas publicaçōes eruditas no campo dos estudos monetários no Brasil é a de Dorival Teixeira Vieira, "A evolução do sistema monetário brasileiro", Revista de administração, I (junho, 1947), 3-385 que deve ser comparada com Liberato de Castro Carreira, História financeira e orçamentäria do Império do Brasil. Rio de Janeiro, 1889 e Amaro Cavalcanti, Resenha financeira do ex-império do Brasil em 1889. Rio de Janeiro, 1889. 
Em número bastante expressivo de publicações, houve a tendência de encarar a história financeira do Império assim como sua atitude em relação à diversificação econômica, através da carreira do desafortunado Irineu Evangelista de Souza, barão e visconde de Mauá. E' muito cêdo para se discernir qualquer correlação entre a atitude dos historiadores para com Mauá e a demonstrada para com o Segundo Reinado.

Mauá foi figura extraordinàriamente representativa da expansão econômica do Brasil no período que se estende do término do tráfico de escravos à crise econômica de 1864 e o início da Guerra do Paraguai no ano seguinte. Do material apresentado em sua auto-defesa publicada em 1878 e reeditada há pouco por Ganns, e nas biografias de autoria de Alberto de Faria e Lídia Besouchet (85), emerge o retrato de um homem originário da humilde pequena burguesia do Rio Grande do Sul, escriturário numa firma inglêsa que se tornou importador no Rio de Janeiro, comprou os estabelecimentos de Ponta d'Areia em Niterói quando as tarifas de 1844 protegeram algumas indústrias locais, estendeu suas operações a atividades bancárias quando o término do tráfico de escravos liberou os capitais para investimento em outras emprêsas, e depois às estradas de ferro, à navegação costeira que se estendia até o Amazonas, e mais tarde - como indicam Lídia Besouchet e Teixeira Soares (86) - - às atividades financeiras de grande escala em Montevidéu quando o livre-cambismo fêz desta metrópole centro de uma vasta rêde comercial distribuidora com ramificações no Rio Grande do Sul. Lídia Besouchet vê nêle o representante da incipiente burguesia brasileira. Como a recém-publicada Autobiografia indica, lutou pela redução da intervenção governamental na economia nacional, preconizando a limitação do contrôle sôbre a autorização de funcionamento para as sociedades anônimas bancárias e sôbre a entrada de capitais estrangeiros a fim de aproveitar as disponibilidades dos mercados monetários inglês e francês. Esste defensor da iniciativa privada foi à falência em

(85). - Irineu Evangelista de Souza, Autobiografia ("Exposição aos credores e ao público") seguida de ("O meio circulante no Brasil"), 2a. ed., prefaciada e anotada por Cláudio Ganns. Rio de Janeiro, 1943. Alberto de Faria, Mauá. Irineu Evangelista de Souza, barão e Viseonde de Maú. Rio de Janeiro, 1926; Lidia Besouchet, Maúa y su epoca. Buenos Aires, 1940.

(86). - Irineu Evangelista de Souza, visconde de Maú, Correspondência política de Maúa no Rio da Prata (1850-1885). Prefácio de notas de Lídia Gesouchet. São Paulo, 1943; Teixeira Soares, "Mauá, o Uruguai e o Brasil", RIHGB, 209 (outubro-dezembro, 1950), 2-213. 
1875 quando o govêrno imperial recusou seu pedido de assistência financeira pelo Banco do Brasil.

Porque Mauá falhou, como seu êmulo do século XX, Farquhar, é assunto ainda não resolvido. Cláudio Ganns, Lídia Besouchet, Anyda Marchant (87) e Alberto Faria, apologistas de suas operações, acreditam que Mauá foi derrotado pela indiferença de uma poderosa economia de "plantação" às oportunidades oferecidas pelo capitalismo comercial, pela má vontade dos interêsses bancários anglo-portuguêses e pelo duplo papel de Mauá como empreendedor financeiro e industrial. Como seu contemporâneo Vergueiro, teve grande visão, porém prematura. Êste ponto de vista não diverge do esposado pelo nacionalismo econômico brasileiro das últimas décadas. O primeiro apologista de Mauá foi Alberto Faria, advogado ligado a grandes emprêsas e que contribuiu para frustar os esforços do sindicado Farquhar, quando êste tentou adquirir o contrôle sôbre a Companhia Docas de Santos em 1912-1913. Castro Rebelo (88), o único historiador que lutou contra a "lenda" Mauá, viu nêle apenas hábil financista favorecido por elementos bem colocados no govêrno, um homem que explorou emprêsas quando prósperas e as abandonou na adversidade, que transformou num monopólio a navegação do Amazonas, e que procurou a intervenção governamental quando dela precisou. Abordar biogràficamente a história econômica do Império é interessante, mas é enganoso generalizar sôbre o destino de empreendimentos econômicos tendo como base a experiência de Mauá. Os contemporâneos não se impressionaram excessivamente pela sua importância e nem sua sorte os impediu de empreender, com sucesso, inovações econômicas, tais como bancos, iluminação e transportes públicos, estradas de ferro e, mesmo, fábricas de tecidos de algodão. Diferiam certamente de Mauá no evitar operações internacionais. Cabe aos historiadores investigar o motivo porque algumas destas emprêsas prosperaram enquanto as de Mauá declinaram.

Parece fora de questão, como jovem historiadora brasileira mostrou em série de artigos (89), que a bancarrota de

\footnotetext{
(87). - Anyda Marchant, "A sorte não o permitiu", RHGB, 192 (julho-setembro, 1946), 46-59 e seu "A New Portrait of Mauá, the Baker: a Man of Business in XIXth Century Brazil", HAHR, XXX (novembro, 1950), 411-431.

(88) . - E. Castro Rebelo, Mauá, restaurando a verdade. Rio de Janeiro, 1932.

(89). - Nícia Vilela Luz, "Aspectos do nacionalismo econômíco brasileiro. Esforços em prol da industrialização", Revista de História, VIII, (outubrodezembro, 1957), 357-378; ibid., IX (janeiro-março, 1958), 27-41. Artigos subseqüentes tratam dêsse assunto no período posterior a 1889 .
} 
Mauá em 1875 foi apenas uma das muitas manifestações locais da crise econômica mundial que eclodiu nas duas décadas a partir de 1873. Ao traçar as raízes do nacionalismo econômico brasileiro, Nícia Vilela Luz esclareceu, também, as origens da industrialização brasileira, especialmente no que concerne à polêmica sôbre protecionismo. Até 1875 a política governamental imperial de proteção moderada não satisfazia nem os partidários do comércio livre e nem os do protecionismo. Foi produto do conflito surgido, de um lado, entre arraigados interêsses agrários e comerciais e a acentuada dependência em que se achava o govêrno das rendas alfandegárias, e do outro, fabricantes em pequena escala de mercadorias de consumo, agraciados com concessões de privilégios industriais e nacionalistas ardentes. Depois de 1875, de acôrdo com Nícia Vilela Luz, os protecionistas reclamaram de modo persuasivo maior proteção, apontando para o declínio dos preços da maioria dos artigos de exportação brasileiros, o aumento do desemprêgo rural e urbano, e o desequilíbrio da balança de pagamentos. O resultado era um clima de instabilidade econômica, ou como disse Nícia Vilela Luz "uma atmosfera de insegurança" particularmente acentuada entre 1880 e 1886 . Como conseqüência das concessões protecionistas arrancadas de um govêrno relutante, as emprêsas industriais existentes fortaleceram-se enquanto se estabeleceram, simultâneamente, os fundamentos da expansão industrial da década de 1890, nos primeiros anos da República.

Revendo a historiografia recente sôbre o Segundo Reinado, durante os anos que foram provàvelmente os de maior sucesso, isto é, as duas décadas posteriores a 1850, é evidente que os investigadores levantaram questões sôbre as relaçōes entre a política e a economia que os "brasilianistas" não podem ignorar. Hoje, um século depois da éra de conciliação do Segundo Reinado, é tempo de se examinarem de perto as relações entre o compromisso liberal-conservador e o crescimento econômico que se iniciou com a retirada do capital investido no tráfico de escravos, tornado ilegal, e terminou com a crise econômica de 1864 e a eclosão da Guerra do Paraguai. À espera de comprovação está a hipótese de Licínio Cardoso, segundo a qual o Imperador, os conservadores e alguns liberais acolheram favoràvelmente o conflito com o Paraguai como meio de distrair a atenção do povo das medidas inéptas aplicadas durante a crise de 1864 , e sufocar a revolta dos li- 
berais radicais contra a política bipartidária (90). As experiências realizadas nas décadas de 1850 e 1860 com novas formas de trabalhos e de empreendimentos econômicos, assim como a crise econômica de 1864 sugerem a idéia de que se tratava de sintomas de desenvolvimento do Brasil centro-sul, procurando os brasileiros acomodar novas instituições à estrutura do antigo regime. $\mathrm{O}$ colapso da conciliação, sob os ataques dos liberais-reformistas da década de 1860 , o aparecimento do Clube Liberal Reformador em 1869 com o "slogan", "Reforma ou Revolução", e a publicação do Manifesto Republicano em 1870 (91) pode ser considerados como manifestações políticas da crise interna.

Convencionou-se há tempos atribuir o agrupamento da crise interna das duas últimas décadas do Segundo Império a quatro fatôres capitais: a manifestação do Brasil do conflito ocidental entre o secularismo e o ultramontanismo (1872-1875), (a Questão Religiosa), a sanção do Partido Conservador à abolição sem indenização, a aceitação gradual da idéia de uma República brasileira como fato inelutável, resultado da desilusão diante dos rumos tomados pela monarquia e, finalmente, a par-

(90). - A Margem da História do Brasil, 129-130 especialmente em sua críptica nota em Carneiro et al., A Margem da História da República, 294. Observação similar foi feita por Cruz Costa, Contribuição à história das iđéias no Brasdr, 185,186, que cita Euclides da Cunha, A Margem da História (Pôrto, 1913), 345-356. Pelham Horton Box aventa variação a essa hip6tese. Sugere que o govêrno imperial nos princípios da década de 1860, sob forte pressão exercida pelos criadores de gado sul-riograndense no sentido de intervir no Rio da Prata, teve de escolher "entre uma guerra civil e um conflito externo". The Origins of the Paraguayan War (Urbana, Illinois, 1927), 279.

Como era de se esperar, os aspectos militares da Guerra do Paraguai exerceram forte influência sôbre os historiadores brasileiros. Ver Augusto Tasso Fragoso, História da guerra entre a Tríplice Aliança e o Paraguai. 3 vols., Rio de Janeiro, 1934; Otávio Pereira de Souza, "História da Guerra do Paraguai", RIHGB, 102 (1927), 7-497; Visconde de Ouro Prêto, "A marịnha de outrora. Subsídios para a história", ibid., 166 (1932), 5-381. Opinião amarga sôbre o papel desempenhado pelos Estados Unidos da América na Guerra é apresentada por Eduardo Prado em. A ilusão Americana. Prefácio de Afonso F. Schimidt (4a. ed., São Paulo, 1933), 124 ff. Para os aspectos econômicos e políticos do papel do Brasil na guerra, ver o material sôbre as atividades de Mauá no Rio da Prata e as de José Antônio Soares de Souza, "A margem de uma política (18501852)", RIHGB, 221 (outubro-dezembro, 1953), 3-43 e seu "O general Urquiza e o Brasil", ibid., 206 (janeiro-março, 1950), 3-101. Opinião argentina recente é encontrada em Ramón J. Cárcano. Guerra del Paraguas. Origenes y causas. Buenos Aires, 1939.

(81). - Reimpresso em Contribuiçōes para a biografia de D. Pedro II, 553-563. 
ticipação efetiva de oficiais do exército brasileiro há muito desencantados com o Segundo Reinado. Na historiografia recente, nem a escola conservadora e nem a liberal introduziram novos fatôres à análise convencional. Diferem consideràvelmente no destaque que dão a um ou mais fatôres, e no grau em que investigam êstes fatôres. Com efeito, cada escola procura resposta a questões diferentes, porém relativas a fatos aproximadamente da mesma época. Os conservadores parecem perguntar: "Por que o Império caiu?" e os liberais: "Que havia de errado nos primórdios do movimento republicano?".

No O ocaso do Império (1925) (92), Oliveira Viana, discípulo de Alberto Tôrres que por uma vez era um republicano desiludido e ardente nacionalista, resumiu o ponto de vista dos historiadores conservadores tanto dos mais antigos como dos de após-guerra. O Império caiu porque estava fraco, não porque o movimento republicano fôsse forte. Tanto os liberais como os conservadores eram políticos oportunistas faltando-lhes a maturidade e o requinte políticos do Imperador. A crítica estrangeira agitou a questão da escravidão depois de 1870, a abolição destruiu a lealdade dos fazendeiros ao Império e os empurrou para o Partido Republicano. O republicanismo, importação estrangeira, possuia pouca atração positiva: o pequeno eleitorado perdera a fé nos ideais da Constituição Imperial de 1824 , mas o republicanismo era um pobre substituto. Sua "penetração social e geográfica" era pequena, a maior parte dos seus clubes ( 89 por cento) e de seus jornais ( 73 por cento) concentravam-se nos centros urbanos do sul do Brasil. Os positivistas eram o único elemento verdadeiramente republicano, mas. seus cinqüenta e três membros contribuintes (1889) eram infinitamente menos numerosos do que os membros dos pequenos partidos republicanos. Desde que os partidos monárquicos estariam ideològicamente falidos e o republicano exercia apenas um magnetismo negativo, só uma explicação restava a Oliveira Viana para a queda do Império: um grupo dentro de republicanos hipnotizou o crédulo Marechal Deodoro no senti-

(92). - Francisco José de Oliveira Viana, o ocaso do Império. São Paùlo, 1925 e edição subsequiente, São Paulo, 1933. Foi originàriamente preparado para Contribuiçōes para a biografia de D. Pedro Ir. Há análise sôbre o conservadorismo de Oliveira Viana na resenha de Emílio Willems sô. bre a recente edição da Evolução do povo brasileiro, em HAHR, XXXVII (novembro, 1957), 499-500. Cf. Afonso Celso, oito anos de parlamento. Poder pessoal de D. Pedro II, Reminiscências e notas. 2a. ed., São Pau1o, 1928 e seu Visconde de Ouro Prêto (exertos biográficos). Com acréscimos e anexos entre os quais o "Advento da ditadura militar no Bra. sil". Pôrto Alegre, 1935. 
do de proclamar a República. Assim, a "questão militar" recebeu maior atenção do que a abolição, o republicanismo ou o positivismo na imagem conservadora, e concisa, bem apresentada que Oliveira Viana nos oferece dos vinte anos entre 18701889 .

A ênfase marcante dada ao militarismo pela escola historiográfica mais antiga é menos notada na historiografia recente, para a qual os revisionistas ofereceram contribuições significativas. E' digno de nota o dado da melhor síntese sôbre o fim do Império aparecer nos capítulos introdutórios da História da República de José Maria Belo, e que em 1940 o autor sentisse que a "República expiava até hoje não apenas os seus erros, mas, também, os legados pelo Império... a herança de cinqüenta anos de hesitações sôbre a escravidão" (93). Os liberais revisionistas concordam em que os brasileiros politicamente conscientes estavam desiludidos com o Império da última década. A julgar pela opinião de um antigo republicano Felisberto Freire (1891) (94), e mais recentemente pela de José Maria Belo e outros, a parte desempenhada pelos militares foi decisiva apenas porque a desilusão, o abolicionismo e as tradições republicanas criaram "condições morais e sociais" para a República. $\mathrm{Na}$ análise efetuada pelos historiadores revisionistas; o exército aparece como instrumento, não como criador da vontade do povo.

As duas escolas da historiografia de após-guerra mostram unânimidade significativa no trato da "questão religiosa" da década de 1870 . Não criticam a atitude regalista do Imperador quando confrontada com o ultramontanismo ressurgente no decênio de 1870. Em essência, abandonaram a discussão polêmica aos partidários do clericalismo ou do secularismo. Duas análises, entre muitas, apresentam os pontos de vista básicos. O trabalho da Irmã Thornton, The Church and Free-

\footnotetext{
(93). - José Maria Belo, História da República, 1889-1945, Adenda 1945-1954. (Síntese de sessenta e cinco anos de vida brasileira), (3a. ed., São Paulo, 1956), 38 .

(94). - Defesa eloquiente das origens da república apareceu em Felisbelo Freire, História Constitucional da República dos Estados Unidos do Brasil. 3 vols., Rio de Janeiro, 1894-1895 e deve ser consultada juntamente com o advento da República no Brasil de Cristiano B. Ottoni. Rio de Janeiro, 1890. Ambos merecem novas edições. Interpretações recentes podem ser encontradas em Cardoso, A margem da República, em Carneiro et al. A margem da história da República, 320-333; Evaristo de Moraes, Da monarchia para a República (1870-188). Rio de Jáneiro, 1936 e em Lauro Sodré, "A proclamação da República", Terceiro Congresso de História Nacional, Anais, VII, 349-416,
} 
masonry in Brazil (95) provàvelmente será por muito tempo a apologia clássica do ultramontanismo brasileiro. Sua principal premissa é a de que o regalismo de Pombal, o liberalismo do século XIX e a franco-maçonaria atrairam os clérigos brasileiros e minaram a influência espiritual da Igreja Católica Romana. Quando o govêrno imperial se recusou a conceder seu placet à encíclica papal (1864) contra a participação dos católicos nas lojas maçônicas, bloqueou as tentativas do episcopado brasileiro, hàbilmente conduzido pelo recémnomeado Bispo de Olinda (96), para erradicar o liberalismo maçônico das irmandades leigas. A anistia concedida pelo Imperador, em 1875, a dois bispos recalcitrantes, concluiu a Irmã Thornton, prova a derrota da política governamental de usar a livre-maçonaria para apoiar o regalismo. Contràriamente ao ponto de vista clerical da Irmã Thornton, Basílio de Magalhães (97) atribuiu a recusa do placet imperial ao fato do Imperador ter percebido que os membros de tendência liberal nas irmandades religiosas não representavam nenhuma ameaça anti-católica. Longe de derrota, a controvérsia findou com a vitória do regalismo, argumenta. Os outros dez bispos brasileiros mantiveram "silêncio tímido e indesculpável" e não se esboçou nenhum apôio popular aos bispos sublevados.

(95). - Sister Mary Crescentia Thornton, The Church and Freemasonry in Brazil, 1872-1875. A study in Regalism. Washington, D. C. 1948 que apresenta bibliografia extensa. Participando de uma atitude também favorável ao clero, embora sem o mesmo critério científico, acha-se Flávio Guerra, A questão religiosa do Segundo Império. Fundamentos históricos. Prefácio de Barbosa Lima Sobrinho. Rio de Janeiro, 1952. Historiadores interessados no papel desempenhado pela Igreja Católica Romana do Brasil devem ser consideràvelmente gratos ao exaustivo levantamento feito por José Carlos de Macedo Soares, "Fontes da história da Igreja Católica no Brasil", RIHGB, 220 (julho-setembro, 1953), 7-338. Também útil é de Apolônio Nóbrega, "Dioceses e bispos do Brasil", ibid., 222 (janeiro-março, 1954), 3-328.

(96). - A posição dos bispos é claramente apresentada na edição recente de D. Frei Vital Maria Gonçalves de Oliveira, Instrução pastoral sôbre a maçonaria e os jesuítas Petrópolis, 1957 e em D. Silvério Gomes Pimenta, em resposta a ataques de maçon influente e anti-clerical, Resposta ao discurso do sr. conselheiro Saldanha Marinho. Petrópolis, 1956. Ver também Jorge Lima, D. Vital. Rio de Janeiro, 1944.

(97). - Basílio de Magalhães, Estudos de história do Brasil, 89-162, que apresenta breve bibliografia, assim como Hélio viana, em Estudos de história imperial, (São Pauło, 1950), 279-294. O ponto de vista secular é encontrado também em Lídia Besouchet, José Maria Paranhos. Visconde do Rio Branco. Ensaio histórico-biográfico, (Buenos Aires, 1944), 179-249, em Viveiros de Castro, "A questão religiosa", em Contribuiçōes para a biografia de D. Pedro II, João Dornas Filho, o padroado e a igreja brasilleira. São Paulo, 1938 e na apreciação sugestiva de Cruz Costa em Contribuição, 115-129. 
O fato dos historiadores de décadas recentes darem tanta atenção à "questão religiosa" não serve, precisamente, como medida adeqüada para avaliar seu significado na demissão do Segundo Reinado. Os modernos "brasilianistas" não discutem a generalização largamente sustentada de que a alienação dos clérigos foi fator primordial no colapso do Império em 1889 (98), nem o fato da Igreja Católica mostrar o que Nabuco chamou de "indiferença" (99) ao abolicionismo, enquanto reagia vigorosamente ao regalismo.

Se a influência da Igreja sôbre a política no fim do Império, está ainda por ser avaliada, análises da história intelectual do Império trouxeram nova luz sôbre a influência do positivismo nos primórdios do movimento republicano. Apresentada como tese para a Cadeira de Filosofia da Universidade de São Paulo e em seguida ampliada em Contribuição à história das idéias no Brasil (100), há o estudo cuidadosamente documentado de João Cruz Costa, outro exemplo da maturidade da erudição brasileira e produto da atividade da missão cultural francesa desenvolvida em São Paulo durante as décadas de 1930 e 1940 .

A obra consiste essencialmente no exame das correntes filosóficas e sua relação com a política e a sociedade brasileiras no século XIX. Ligando idéias à grupos de interêsses, Cruz Costa percebeu o advento de um nôvo grupo de brasileiros uma classe média de origens burocráticas, comerciais e profissionais - tornando-se politicamente importante depois de 1870. Interêsses práticos levaram-nos a rejeitar o "ecletismo espiritual" em troca das ciências positivas e finalmente do positivismo. Uns poucos encontraram uma nova fé no positivis-

\footnotetext{
(98). - Em seu prefácio a Irmã Thorton afirma ter a controvérsia "contribuído indiretamente" para a queda do Imperio, citando Martin, "Causes of the Collapse of the Brazilian Empire". Mais tarde argumenta ter a controvérsia "contribuído de modo importante" para sua "queda final". Op. cit., vii e 153 nota 1 . Para a sua afirmação de que a "controvérsia religiosa... empanou sèriamente o prestígio do Império" não oferece Martin evidência documentada. Op. cit., 14. Opinião semelhante também sem apôio na evidência encontra-se em Oliveira Lima, "o Império brasileiro, 1822-1889, (São Paulo, 1927), 180. Nào se deve esquecer que Teixeira Mendes, que mais tarde foi figura proeminente no movimento positivista brasileira, abandonou a Igreja Católica em 1874 por ser esta antagônica às suas "aspirações republicanas"; João Cruz Costa, Esbozo de una história de las ideas en el Brasil, (México, D. F., 1957), 34.

(99). - Joaquim Nabuco, Minha formação, (Rio de Janeiro, 1934), 224.

(100). - Contribuição à história das idéias no Brasil (o desenvolvimento da filosofia no Brasil e a evolução histórica nacional). Rio de Janeiro, 1956, uma expansão de sua tese, $O$ desenvolvimento da filosofia no Brasil no século XIX. São Paulo, 1950. Foi publicada condensação em espanhol, Esbozo de una historia de las ideas en el Brasil. México, D. F., 1957.
} 
mo de Comte, outros consideraram-no doutrina inteiramente compatível com os movimentos progressistas da abolição e do republicanismo que então agitavam o Brasil. No entanto, o grupo de positivistas organizados e disciplinados em volta de Miguel Lemos e Teixeira Mendes no seu Apostolado positivista "pouco ou quase nada fizeram pelo advento da República" como Cruz Costa insiste em dizer (101). A explicação dêste paradoxo aparente foi localizada por Cruz Costa na rigidez doutrinária e na ênfase de quase culto religioso que Lemos e Teixeira Mendes deram ao Apostolado após seu rompimento com Pierre Laffitte, chefe titular do positivismo depois da morte de Comte. Insistiam na adesão estrita à doutrina de Comte segundo a qual, na fase atual transitória imediatamente precedente ao estágio positivista, os positivistas deviam abster-se de funções públicas. Laffitte, homem prático, incitava seus colegas brasileiros a adotar o princípio de "relatividade" que êstes rejeitavam. Tal inflexibilidade doutrinária e ortodoxa religiosa, com o fim de manter a conformidade interna não apenas causou a perda de muitos adeptos potenciais, mas também afastou alguns antigos membros "heterodoxos" e influentes como Benjamin Constant, que abandonou o Apostolado por um positivismo pragmático. Assim, o positivismo não teve papel efetivo no movimento republicano. Apenas ao fato de Benjamin Constant gozar de efêmera autoridade, durante poucas semanas, no govêrno provisório da República, deve-se a "fama inexata", grangeada pelos líderes do Apostolado, "de haver sido o positivismo o criador da República no Brasil" (102). Por outro lado, Cruz Costa salienta que a atitude não-militante $\mathrm{e}$ essencialmente negativa que os "ortodoxos" demonstraram para com o republicanismo e o abolicionismo não pode ser interpretada como indiferença, conforme sustenta Oliveira Tôrres na análise polêmica e mais limitada que nos oferece do positivismo (103).

Estudo pioneiro, excelente em muitos aspectos, a Contribuição de Cruz Costa deixou, entretanto, de explorar satisfatòriamente as razões que levaram o positivismo, no Brasil, a trocar a luta política pela calma do cláustro. Com efeito, Cruz Costa oferece só uma hipótese para êste problema: o desêjo de encontrar num "sistema simples", uma panacéia e, em segun-

\footnotetext{
(101):-Contribuição, 143, 242. Cf. opinião de Felisberto Freire, História constitucional da república dos Estados Unidos do Brasil, I, apêndice, 401-414. (102). - Contribuiçãa, 245

(103). - Joāo Camilo de Oliveira Tôrres, o positivismo no Brasil. Prefácio de Euríalo Canabrava. Rio de Janeiro, 1943.
} 
do lugar, uma adesão fanática a êste sistema como meio de evasão a seu "secreto horror da realidade nacional" (104). E' de se esperar que o trabalho de Cruz Costa estimule estudos sôbre os positivistas eminentes, engenheiros e homens de negócios do Brasil do século XIX, assim como sôbre as repercussões do movimento em outros níveis da sociedade.

Ao procurar examinar a "realidade nacional" especialmente as correntes econômicas, sociais e ideológicas que se cruzavam no movimento republicano, fizeram os historiadores revisionistas contribuições notáveis. Publicações recentes revendo os problemas da agricultura, trabalho e política cafeeiros, no findar do Segundo Reinado, trouxeram esclarecimentos sôbre nova classe média que surgia depois de 187.0 e, indiretamente, sôbre as origens da República. Quando se iniciou no Vale do Paraíba, na primeira metade do século XIX, o primeiro ciclo cafeeiro, os fazendeiros consideravam o tráfico de escravos e a escravidão como único meio de suprimento e forma de trabalho disponível. Como se mostra num estudo sôbre certa região do Vale, a de Vassouras (105), o fim do tráfico de escravos, a erosão do solo e a velhice dos escravos existentes, puseram fim a êste ciclo cafeeiro, enquanto; depois de 1875, outro se iniciava em terras virgens de São Paulo. Os cafeicultores do Vale apoiaram o Partido Conservador até 13 de maio de 1888 porque êle poderia servir de eventual barreira à emancipação dos escravos, e, só depois, êstes conservadores foram impelidos pela desilusão e ressentimento ao Partido Republicano. A segunda fase, fase paulista do ciclo cafeeiro brasileiro que Pierre Monbeig considerou como um "episódio na expansão da civilização capitalista que se desenvolvia nas praias do Atlântico" (106), foi dirigida por fazendeiros imbuidos de espírito comercial inovador. De acôrdo com Pionniers et planteurs de São Paulo êstes empreendedores ("grandes senhores da terra possuídos de espírito comercial" e não patriarcas senhoriais) transformaram as lavouras de café em emprêsas "industriais" elevando ao máximo a produção do café e cortando o plantio su-

\footnotetext{
(104). - Contribuição, 248. Sôbre a rejeição positivista da realidade ver Sérgio Buarque de Holanda, Raices del Brasil, (México, 1955), cap. vi, especialmente págs. 142-147.

(105). - S. J. Stein, Vassouras, A Brazilian Cofee County, 1850-1900. Cambridge, Mass., 1957.

(106). - Pierre Monbeig, Pionniers et planteurs de São Paulo. Cahiers de la Fondation Nationale des Sciences Politiques, n.o 28 (Paris, 1952), 93. Monbeig em sua monografia salienta o período depois de 1929; seu resumo histórico deve ser comparado com o de Sérgio Buarque de Holanda na introdução a Davatz, Memórias de um colono no Brasil.
} 
plentar de outros gêneros alimentícios. As fazendas paulistas, eram, assim, fonte de renda a ser investida em empreendimentos modernos tais como a Companhia Docas de Santos, Companhias de Estradas de Ferro: Paulista, Sorocabana e Mogiana.

Era essencial aos paulistas que abriam fazendas na década de 1870, mão-de-obra barata e adeqüada. Da Africa não provinham mais escravos, o comércio entre as províncias, pelo qual os escravos nortistas eram vendidos para o Sul, esgotava-se, e. a emancipação gradual que se podia entrever pela Lei do Ventre Livre de 1871 produzia poucos libertos ou crianças livres. O artigo biográfico de Ricciardi (107) mostra como os fazendeiros paulistas mais progressistas liderados por Antônio de Queiroz Teles transformaram a experiência pioneira de Vergueiro. Filho de amigo íntimo e êmulo de Vergueiro, antigo presidente da Companhia de Estradas de Ferro Mogiana, Queiroz Teles conhecia as queixas dos agricultores sôbre a deficiência de mão-de-obra e viajara pela Europa Ocidental em inspecção de estudos sôbre a administração de ferrovias. O artigo de Nícia Vilela Luz (108), com efeito, suplementa o de Ricciardi. Para enfrentar o comércio inter-provincial, São Paulo taxou de forma elevada (1881) os escravos trazidos para a província, sós ou em companhia dos senhores, e em 1886, como mostrou Nícia Vilela Luz, o govêrno provincial subvencionou com fundos públicos uma sociedade de emigração para promover a importação de braço europeu alugado, como proletariado rural (109). Pode-se sugerir a hipótese da intervenção governamental e o empreendimento particular terem preservado a grande propriedade monocultora como a maior unidade de produção na economia cafeeira brasileira, lançado as bases pa-

(107). - Adelino R. Ricciardi, "Parnaíba, o pioneiro da imigração", RAMSP, IV (XLIV, 1938), 137-184.

(108). - Nícia Vilela Luz, "A administração provincial de São Paulo em face do movimento abolicionista", Revista de administração, II (dezembro, 1948), 80-100.

(109) - Cf. Djacir Menezes, o outro Nordeste: formação social do Nordeste (Rio de Janeiro, 1937), $152 \mathrm{ff}$. Menezes sugere que as raízes da cruzada abolicionista podem ser encontradas no interêsse dos agricultores paulistas por um suprimento de trabalho mais elástico, em seus investimentos financeiros em estradas de ferro, emprêsas comerciais e industriais, e na esperança dos comerciantes e industrialistas brasileiros num aumento do consumo. A hipótese que L. C. A. Knowles apresenta em "British Tropics" sôbre a interrelação da construção de estradas de ferro com a abolição da escravidão e que Normano confinou a um rodapé, não foi examinada com respeito ao Brasil. Ver Normano, Brasil, 79 nota 45 e de Knowles Economic Development of the Overseas Empire, 1763-1914. (Londres, 1924), 121, ou seu Economic Development of the British Overseas Empire (2a. ed., 3 vols.,. Londres, 1928-1936), I, 121. 
ra o programa de valorização do café de 1906 e fornecido argumento aos industrialistas que, no final da década de 1890, reivindicaram tarifas alfandegárias protecionistas (110).

Estudos recentes sôbre as origens do movimento republicano em São Paulo, revelam que a incapacidade do Partido Republicano Paulista em dominar o problema da abolição, dividiu o partido ainda incipiente, enfraqueceu seu papel político até os últimos meses do Império. José Maria dos Santos focaliza em Os republicanos paulistas e a abolição (111), a evolução do Partido Republicano Paulista (PRP) de 1870 a 1888, dando-nos uma síntese notável pela sua percepção, lucidês e finura. Se o Partido Republicano Paulista foi um microcosmo dos outros partidos republicanos do Brasil, é fato não esclarecido; o significado dominante dêste estudo consiste no fato do Partido Republicano Paulista ter sido o centro do movimento republicano. De acôrdo com José Maria dos Santos, os radicais ou liberais históricos e alguns abolicionistas fundaram o Partido Republicano em 1870 no Rio. Em São Paulo o grupo contava, entre outros, com os liberais Prudente de Morais e Campos Sales, e os abolicionistas Bernardino de Campos e Luís Gama. Sob a direção de Quintino Bocaiuva os republicanos do Rio publicaram manifesto oferecendo, aos radicais liberais, autonomia das províncias (espécie de direitos estaduais) e, aos abolicionistas, declaração em favor de eventual abolição. Entretanto, quando o grupo paulista organizou um partido, anos depois, a abolição ligada à indenização foi tratada como problema a ser resolvido por cada província em particular. Os abolicionistas desiludidos gradualmente deixaram de participar ativamente do partido. Mas, como o partido esperava reter o apôio popular trazido pelos abolicionistas, nem Bernardino de Campos e nem Luís Gama (112) foram repudiados. Na política local os republicanos de São Paulo tiraram proveito dos votos dos partidos Liberal e Conservador, o que já está con-

\footnotetext{
(110). - S. J. Stein, The Brazilian Cotton manufacture. Textile Enterprise in an Underveloped Area (Cambridge, Mass., 1957), 81-97. Cf. Nícia vilela Luz, "Aspectos do nacionalismo brasileiro", Revista de História, XI (abril-junho, 1958), 311-312.

(111). - Rio de Janeiro, 1942.

(112). - Cf. Sud Menucci, o precursor do abolicionismo no Brasil (Luís Gama), São Paulo, 1938. Publicações numerosas têm a tendência de exaltar, talvez indevidamente, o papel de Nabuco na abolição. Cf. Joaquim Nabuco, O abolicionismo. São Paulo, 1938 e para manifestação maís antiga sôbre o seu abolicionismo "A escravidão", RIFGB, 204 (julho-setembro, 1949), 10-106. Ver também de Gilberto Freyre, Joaquim Nabuco. Rio de Janeiro, 1948 e de Carolina Nabuco, The Life of Joaquim Nabuco. Stanford, 1950 .
} 
substanciado na cuidadosa edição feita por Camargo Aranha das cartas de Américo Brasiliense sôbre a primeira campanha eleitoral do PRP (113). No curso da retirada dos republicanos, em face do abolicionismo, o editor e administrador do portavoz republicano, o jornal Província de São Paulo, foi demitido, em 1884 devido às suas tendências abolicionistas. Foi então que abastado fazendeiro republicano (irmão de Campos Sales), supriu o jornal com fundos a fim de manter sua publicação (114). Tornou-se claro em 1885, segundo J. M. dos Santos, como a orientação do Partido Republicano Paulista havia comprometido sèriamente o movimento. Quando o Parlamento Imperial começou a discutir, em 1885, o projeto de lei que libertava os escravos sexagenários sem compensação, correram rumores no Rio que dois deputados do PRP, Campos Sales e Prudente de Morais, estavam realmente do lado dos escravagistas. Santos salienta que os líderes do Partido Republicano Paulista reafirmaram então sua posição abolicionista com o fim de atrair votos do número crescente de abolicionistas nos centros urbanos.

Está implícita na maneira pela qual J. M. dos Santos trata o Partido Republicano Paulista até o decreto de emancipação de 1888, a tese de que o conflito latente entre a reforma e revolução no liberalismo do século dezenove, a luta entre evolucionistas e revolucionistas, entre pragmatistas e idealistas, surge como luta dentro do partido entre os abolicionistas intransigentes e os contemporizadores. Esta é contribuição significativa para a historiografia dos primórdios do movimento republicano. Segundo mostram trabalhos recentes de Boehrer e Dornas Filho (115), o conflito reaparece no Partido Republicano do Rio depois da abolição, quando os chefes do partido tiveram de decidir sôbre se permitiriam que o Império caísse por si, evoluindo pacificamente para a República, ou se, seguindo as lições da ação direta, empregada com sucesso pelos abolicionistas nos últimos meses de sua campanha, advogariam a queda violenta das instituições existentes. $\mathrm{Na}$ verdade, Boehrer mostrou que Silva Jardim, o jovem abolicionista que participou do movimento republicano

(113). - J. M: de Camargo Aranha, "A primeira campanha eleltoral do partido republicano pàulista. Canđidatura de Américo Brasiliense", RAMSP, III (XXXV, 1937), 3-66.

(114). - Santos, Os republicanos paalistas, 1911-192. Ver também de Edith Saboła, "Francisco Rangel Pestana", RAMSP, VI (LXI, 1939), 23-42.

(115). - George C. A. Boehrer, Da monarquía à república. Fístória do partido republicano no Brasil. Rio de Janetro, 1954; João Dornas Fulbo, Sîva Jardim, Sāo Paulo, 1936. 
depois de 1888, preconizou a revolta em massa de tôda a nação, com ou sem o apôio das fôrças armadas, citando os levantes pernambucanos de 1817, 1848 e a abdicação forçada de D. Pedro I em 1831 (116). Poder-se-ia depreender das biografias de Silva Jardim e de Benjamin Constant, que na esfera militar oferece paralelo com o primeiro (117), o fato de serem ambos representantes da nova classe média pronta pa-. ra conduzir o republicanismo ao povo e ao exército (118).

Tanto Boehrer em sua análise sôbre o crescimento do. Partido Republicano antes de 1889, como Dornas Filho na sua biografia de Silva Jardim, concordam substancialmente quanto ao fato da luta dentro do partido entre os adeptos da evolução e os da revolução ter chegado ao áuge no Congresso. Republicano Nacional ocorrido em São Paulo em maio de 1889, com Silva Jardim e Quintino Bocaiúva terçando armas pelo. contrôle do Partido. Os conservadores ou republicanos evolucionistas lutavam por eleger Bocaiúva e Silva Jardim rompe então abertamente com Bocaiúva, com a velha guarda republicana de São Paulo e os ex-monarquistas convertidos ao. republicanismo. Depois de maio de 1889 , tornou-se claro que a ala evolucionista do Partido Republicano Paulista herdaria a República. Há considerável perspicácia nas observações irônicas de escritores recentes, um dêles (Afonso Arinos) ao observar que a "República em São Paulo e Minas era o café post-abolicionista, café com braço livre", enquanto outro (Sérgio Milliet) concluiu ter sido a ação de 15 de novembro de 1889 apenas um "coup d'état" desde que "revolução implica em modificação de práticas e costumes, de instituições e filosofias de vida, quando o fato foi que a República mudou sim-. plesmente a forma de govêrno" (119).

(116). - Boehrer, Da monarquia, 238.

(117). - V. L. Cardoso, "Benjamin Constant, o fundador da República", em Car: neiro et al., A margem da história da República, 293-317. Até agora mais extensa, se năo a mais imparcial biografia é a do positivista Rai-: mundo Teixeira Mendes, Benjamin Constant. Esbôeo de uma apreciação. sintética da vida e da obra do fundador da república brasileira. 3a. ed., São Paulo, 1937.

(118). - Sôbre os laços que ligavam a incipiente classe médía e o militarismo, relaçōes que estáo a exigir comprovaçāo adeqüada, ver San Tiago Dantas, Dois momentos de Rui Barbosa, (Rio de Janei+o, 1949), 17-20, citado. em Oliveira Tôrtes, A democracia coroada, 540. Para material disperso. porém muito sugestivo sôbre a classe média iar Gilberto Freyre, ordem e Progresso, 2 vols., Rio de Janeiro, 1953.

(119). - Afonso Arinos de Melo Franco, Um estadista da República (Afrânio de Melo Franco e seu tempo), (3 vols., Rio de Janelro, 1955), I, 231; Sérgio. Milliet em Max Leclerc, Cartas do Brasil. Trađuçāo, prefácio e notas de Sérglo Milliet (São Paulo, 1942), 9. 
$\mathrm{Na}$ ênfase econômica e social dada pela historiografia recente ao período entre 1870 e 1889 , os historiadores parecem rejeitar, por inferência, a velha opinião de que, sem a intervenção militar de 15 de novembro de 1889, o Segundo Reinado teria durado até a morte de D. Pedro II. O tratamento dispensado a certas figuras da classe média como Silva Jardim e Benjamin Constant, sugere a hipótese de ter havido nos grandes centros urbanos do Brasil na década de 1880, largo apôio, maior do que se tem supôsto, ao abolicionismo e ao republicanismo. Deve ser igualmente investigada a tese ligeiramente esboçada por Belo, segundo a qual a luta anterior a 1889 entre os conservadores e radicais dentro do Partido Republicano teria continuado até o fim da Campanha de Canudos em 1897 (120). E', indubitàvelmente, outra maneira de se afirmar que a historiografia recente, relativa a esta éra, transferiu sua atenção, antes circunscrita à ruína do Império, para o nascimento da República.

\section{VI}

$\mathrm{Na}$ história do Brasil do século XIX, historiadores dos últimos tempos vislumbraram as raízes de problemas contemporâneos, mas não lograram achar marcos de referência, nem na monarquia, nem na escravidão, nem na economia monocultora de exportação. Não há tradição claramente perceptível, tal como na reforma do México, que possa servir de farol. Em seu verdadeiro sentido, o estudo dos movimentos revolucionários ocorridos sob o Segundo Reinado, a reedição de panfletos liberais e a ênfase dada ao abolicionismo foram, a bem dizer, tentativas para esquadrinhar o passado em busca de uma tradição liberal. O fato dêstes esforços terem recolhido um bom êxito apenas parcial, tanto reflete a herança conservadora quanto a ausência de correntes ideológicas bem definidas nos anos do após-guerra.

\section{STANLEY J. STEIN}

da Princeton University (E.U.A.)

(120). — Belo, Hist6ria da República, 169-215. 